\title{
Social Security Coverage around the World: The Case of China and Mexico
}

Francisco Perez-Arce, Maria Prados, Erik Meijer, and Jinkook Lee

A future version of this working paper will include data from India.

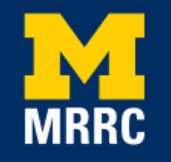

Project \#: R-UM18-Q1 


\title{
Social Security Coverage around the World: The Case of China and Mexico
}

\author{
Francisco Perez-Arce \\ University of Southern California \\ Maria Prados \\ University of Southern California \\ Erik Meijer \\ University of Southern California \\ Jinkook Lee \\ University of Southern California
}

September 2018

\author{
Michigan Retirement Research Center \\ University of Michigan \\ P.O. Box 1248 \\ Ann Arbor, MI 48104 \\ www.mrrc.isr.umich.edu
}

(734) 615-0422

\section{Acknowledgements}

The research reported herein was performed pursuant to a grant from the U.S. Social Security Administration (SSA) funded as part of the Retirement Research Consortium through the University of Michigan Retirement Research Center Award RRC08098401-10. The opinions and conclusions expressed are solely those of the author(s) and do not represent the opinions or policy of SSA or any agency of the federal government. Neither the United States government nor any agency thereof, nor any of their employees, makes any warranty, express or implied, or assumes any legal liability or responsibility for the accuracy, completeness, or usefulness of the contents of this report. Reference herein to any specific commercial product, process or service by trade name, trademark, manufacturer, or otherwise does not necessarily constitute or imply endorsement, recommendation or favoring by the United States government or any agency thereof.

\section{Citation}

Perez-Arce, Francisco, Maria Prados, Erik Meijer, and Jinkook Lee. 2018. "Social Security Coverage Around the World: The case of China, India and Mexico," University of Michigan Retirement Research Center (MRRC) Working Paper, WP 2018-395. Ann Arbor, MI. https://mrdrc.isr.umich.edu/publications/papers/pdf/wp395.pdf

\section{Regents of the University of Michigan}

Michael J. Behm, Grand Blanc; Mark J. Bernstein, Ann Arbor; Shauna Ryder Diggs, Grosse Pointe; Denise Ilitch, Bingham Farms; Andrea Fischer Newman, Ann Arbor; Andrew C. Richner, Grosse Pointe Park; Ron Weiser, Ann Arbor; Katherine E. White, Ann Arbor; Mark S. Schlissel, ex officio 


\title{
Social Security Coverage around the World: The Case of China, and Mexico
}

\begin{abstract}
We describe the current state and recent trends in the landscape of social security programs in China, Mexico, and India. A common thread across these countries is the introduction and recent expansion of old-age pension programs with noncontributory components. We use surveys from the HRSfamily to analyze trends in the levels and correlates of social security coverage in Mexico and China. The most notable development is the increase in public pension coverage for the elderly population. In China, coverage rates for the population 70 and older grew from 33 percent in 2011 to 68 percent in 2015; and in Mexico from 32 percent to 55 percent in the 10 years following 2002. The new programs also caused significant changes on the determinants of coverage in ways that share similarities across countries. Variables such as educational attainment, urban status, and an employment history in the formal sector, were strong predictors of public pension receipt in the earlier survey-waves, but not in the most recent ones for China and Mexico. However, a strong relationship remains, and is unchanged across time, between those same characteristics and the average income pension amount. Likewise, there are no significant changes between them and receipt of benefits from other social programs. Based on these results, we conduct simulations that show, for example, that even rapid transformation of the labor market or education levels of the population would not radically change the proportion covered by pension programs but would largely increase average pension amounts.
\end{abstract}

\section{Authors' acknowledgements}

Corresponding author. Maria Prados. E-mail: Prados@usc.edu. USC. 635 Downey Way, St 505. Los Angeles, CA 90089 . We thank John Phillips (previously at SSA, currently at NIA) for initiating this study. We thank Arie Kapteyn for contributions to the study design and Drystan Phillips for help with data preparation. This analysis uses data or information from the Harmonized CHARLS dataset and Codebook, Version C, as of April 2018 developed by the Gateway to Global Aging Data. The development of the Harmonized CHARLS was funded by the National Institute on Ageing (R01 AG030153, RC2 AG036619, R03 AG043052). For more information, please refer to www.g2aging.org. CHARLS is supported by Peking University, the National Natural Science Foundation of China, the National Institute on Aging, and the World Bank. This analysis uses information and programming codes from the Harmonized MHAS programming codes and Codebook, Version A, developed by the Gateway to Global Aging Data in collaboration with the MHAS research team. The development of the Harmonized MHAS was funded by the National Institute on Aging (R01 AG030153, RC2 AG036619, R03 AG043052). The Harmonized Mexican Health and Aging Study (MHAS) data files and documentation are public use and available at www.MHASweb.org. The MHAS receives support from the National Institutes of Health/National Institute on Aging (R01 AG018016). For more information about the Harmonization project, please refer to www.g2aging.org. The full analysis (not presented in this version of the report) uses preliminary data from wave 1 of LASI and a preliminary version of the Harmonized LASI data developed by the Gateway to Global Aging Data. The development of the Harmonized LASI was funded by the National Institute on Aging (R01 AG030153, RC2 AG036619, R01AG042778, R03 AG043052). The LASI data collections were funded by the government of India and the National Institute on Aging. For more information, please refer to www.g2aging.org. 


\section{Preface}

The global population 60 and older is growing faster than younger age groups throughout the world. Population aging poses an increasing fiscal burden in many countries through increased government spending on pensions and social benefits for the elderly, which has led to reforms such as increased retirement ages. Conversely, some developing countries are creating or expanding programs aiming to increase the fraction of the elderly population that is covered. Within the context of the International Social Security Association (ISSA), social security administrations around the world, including SSA, collaborate to learn from each other. This study provides information about coverage, a key topic of its 2017 to 2019 work plan, in three of the largest emerging economies. In purchasing power parity dollars, the Chinese, Indian, and Mexican economies here studied are the first, third, and $11^{\text {th }}$ largest in the world, respectively; and together they amount to almost 30 percent of the world economy. China, India, and Mexico are the first, second, and tenth largest countries by population in the world; together they cover 37 percent of the world population, and they are the three most common nations of origin among immigrants to the U.S.

Studying these three countries is also of interest because of their varied policy landscapes and the rapid transformations that they are experiencing. According to the International Labour Organization (ILO, 2018), China, Mexico, and India each represent one of the three most common Social Security landscapes: 39 percent of countries have a "contributory scheme only" as in China, 34 percent of countries have a contributory scheme and a noncontributory, meanstested scheme (as in India), and 13 percent have a contributory scheme and noncontributory scheme conditional on not having another pension (as in Mexico). 
Understanding the extent of social insurance from social security programs is crucial for policy design. Furthermore, given current social security programs, we measure coverage which populations are at risk and how changing markets and policies affect them.

\section{Note about India}

This document describes results for China and Mexico. We have also prepared a version of the report that adds analogous material for India, using preliminary and incomplete data from LASI wave 1. However, these have not been cleared for public release yet and, thus, this material is not included in this document, although the text mentions India in places (though not the empirical results). After public release of the LASI data, we will update our analyses for India, and publicly release an updated version of this document that includes India. 


\section{Introduction}

Globally, the population 60 or older is growing faster than all younger age groups. In 2017, there were an estimated 962 million people 60 or older in the world, with Europe having the highest percentage of population 60 or older ( 25 percent). With rapid aging projected to occur in all regions of the world, by 2050 all regions of the world except Africa will have 25 percent or more of their populations at 60 and older (UN 2017).

Population aging poses an increasing fiscal burden in many countries through increased government spending on pensions and social benefits for the elderly. In many countries, policy makers have been actively engaged in debates on how to enhance fiscal sustainability, while maintaining adequate pension income. In several instances, this has led to pension reforms (Carone et al. 2016.) Current and historical changes in social security programs (the number of programs increased, especially in developing countries, but retirement ages increased in developed countries) and in labor markets (increased participation of women, changes in occupational structure/economic growth/other macro developments, increase in formal sector as countries develop) imply likely changes in the structure and level of future social security benefits.

Recent reforms in social security programs in China, Mexico, and India have expanded eligibility to a larger fraction of the population. China followed a series of expansions to its pension system since the mid 2000s. Before 2009, only two institutional mechanisms for income security in old age existed in China: one for urban workers based on social insurance principles and one for civil servants and others of similar status based on the employer liability approach. From 2011 onward, an old-age pension scheme with a noncontributory component was established for the rural populations not participating in the social insurance scheme. It has 
expanded rapidly. A similar program now provides benefits for nonsalaried workers in urban areas as well (Vilela 2013).

In 2007, Mexico introduced a noncontributory pension program for the over 70 -year-old living in small towns, where most people were not eligible for pension benefits from the traditional SS programs (Aguila et al. 2013). It subsequently has been expanded to cover larger towns of up to 30,000 inhabitants (2009), all localities (2012), and for all people older than 65 who are not eligible for other pensions (2013). Current policy proposals include expanding the noncontributory program by removing the conditionality on not receiving another pension so that it becomes truly universal, and also to double the monthly benefit amount.

India reformed its formal pension system by creating the National Pension System or (NPS) in 2004. This is a defined contribution plan that replaced the defined benefit programs that employees of the federal government used to be entitled to. Enrollment is mandatory for federal and state government employees hired in 2004 or later, but it is open on a voluntary basis for individuals who are not government employees as well. Furthermore, many programs have been added to increase coverage of social security. The largest of these, the Indira Gandhi National Old Age Pension Scheme (IGNOAPS), is another program by the central government, which aims to provide about 4 USD for individuals 65 and older in poor households.

We explore these changes, and the factors that affect social security coverage across the three countries using data from the Chinese Health and Retirement Longitudinal Study (CHARLS), the Mexican Health and Aging Study (MHAS), and the Longitudinal Aging Study in India (LASI). We analyze the relative importance of each of the factors, as well as how that has changed across the waves.

We find that the policy changes have resulted in substantial changes in both the levels of coverage and the characteristics of those covered. In the first full wave of the CHARLS data, which corresponds to China in 2011, we find that 33.5 percent of the population older than 70 
had some sort of pension. This proportion had more than doubled to 68 percent four years later. This pattern is not evident in the same way in Mexico because the new program is not recorded in the data as a pension, so the proportion with pension payments remains mostly flat at 25 percent between the first wave of MHAS (2002) and the third wave (2012). However, once we add the number of people receiving either a pension or a payment from the noncontributory program, the pattern is more similar to China. The proportion in that case expands from 33 percent in the first wave to 56 percent in the last wave.

The increase in coverage has been mostly concentrated among people who did not work in the formal sector. In China, this has been mostly concentrated in rural areas and in urban areas outside of government or state-owned enterprises (SOEs). In Mexico, it has also been mostly among the rural, and recently among the informal workers in urban areas. Hence, on average, the characteristics of individuals receiving income support in old ages has changed in important ways. In the early 2000s, characteristics among the Chinese elderly associated with formal employment — such as having higher levels of education, being male, having contributed to a pension program earlier on, living in cities, and having an urban hukou ${ }^{1}$-were significantly positively correlated with receiving a social security retirement payment. By 2014, however, the association with these variables had disappeared or had even become negative. For example, individuals with a rural hukou were more likely to receive a public pension payment. In Mexico, the association between such variables and receiving a public pension payment remains roughly stable across the years when we define as public pensions only those that require a contribution. However, once we add the noncontributory pension programs, a pattern similar to the one for China occurs. The effect of having tertiary education is halved between the first and last wave.

\footnotetext{
${ }^{1}$ The hukou, a governmental identifier household registration system in China, was established in 1955. The hukou status influences employment opportunities (formally and informally so) and social security benefits. (Liu, 2005)
} 
While having worked for pay was positively and significantly associated with receiving a pension in the first wave, its positive association with public pension receipt disappeared by the last one.

The new programs in China and Mexico, however, are not perfect substitutes for the traditional contributory pensions. The basic payments from these programs equaled about 4.2 percent and 5.2 percent for China and Mexico, respectively, of the average payments of the contributory programs or the pension programs for government and formal enterprise employees. Thus, though coverage has increased and may reach universality in the next few years, it is still important to understand the trends and factors that affect access to the programs that provide a higher income.

We find that that the same characteristics associated with having a pension program in the early 2000s are associated with having access to the traditional pensions and to a higher pension benefit and replacement rates in the most recent survey waves. Thus, the patterns that affect things such as the development of the formal sector and urbanization will likely have important consequences in terms of the population more fully supported by social security.

We use the results from our regression models to simulate what would happen to coverage and pension income under alternative scenarios. In particular, we simulate effects of increases in the proportion of the workforce with upper secondary education, rates of urbanization, proportion of men in the population, and increased labor market formalization. Our projections share some commonalities across the two countries: Even large changes in these factors would make little difference for the proportion of elderly covered with social security but would make a large difference in terms of pension income.

The results of the Mexico and China analyses show that though recent reforms and program expansions may go a long way in terms of achieving universality of coverage, the 
evolution of the labor market will still be an important determinant affecting the elderly's economic reality in China and Mexico.

\section{Background: Past and present of social security in China, Mexico, and India}

The three countries studied have experienced important transformations in terms of their social security programs. The public pension programs in China, Mexico, and India covered small fractions of the older population in the 1990s. The existing social security programs in India and Mexico at that time had been developed for the formal sector only, and the formal sector had not grown enough to cover a majority of the population. China had traveled a different path, but reduced government control over the economy left large sectors of the population without coverage. Mexico reformed the pension program in the 1990s, moving from a defined benefit to an individual-account, defined contribution program, but this did not change substantially the extent of the population coverage. India introduced programs for the poor elderly in the mid-1990.

The three countries made significant reforms in the 2000s, making strides toward achieving universal coverage. As in many other countries, Mexico and India introduced and expanded noncontributory pension programs to reach the uncovered population. Mexico introduced a pension program for those older than 70 who live in rural areas, which was subsequently expanded to reach everyone older than 65 not covered by a formal pension. India expanded the noncontributory programs from the 1990s and added a defined contribution plan aimed at the informal sector. India also reformed its government employees' pension scheme and allowed others to enroll in it. China's reforms were similarly complex, consisting of both reforms to their existing programs for government and state-owned enterprise employees, and the creation of new programs for individuals in the rural sector and those without an urban hukou. The latter program has both contributory and noncontributory elements. 


\subsection{China}

In the 1980 s, the existing pension system was comprised by defined benefit programs for urban state sector employees (Giles et al. 2013). In the 1990s, China primarily had two pension programs: one for urban workers based on social insurance principles, and one for civil servants and others of similar status based on the employer liability approach. Following a series of reforms in 2009, 2011, 2014, and 2015, an old-age pension scheme was established for the rural and urban populations not participating in the social insurance scheme, while the civil servants scheme was merged with the social insurance scheme for urban workers.

By 2015, there were three main systems: (1) a pension scheme for urban workers; (2) a pension scheme for civil servants and other government employees; and (3) a pension scheme for rural and urban residents not covered under the first two (World Bank 2016b). The Social Insurance and Individual Accounts Program (SIIAO) merged the pension program for civil servants and for urban workers; and the New Pension Schemes for Rural and Nonsalaried Urban Residents (the Rural Pension) ${ }^{2}$ is the old-age pension scheme for the rural and urban populations not participating in the social insurance scheme (ILO 2018).

China added labor inspectors and sent them to places of employment with the objective of increasing compliance and coverage. These inspections were facilitated by the unification of information systems for employment and social security systems (ILO 2018).

More important in terms of increasing coverage was the introduction of a pension scheme for rural and urban residents not covered by the existing programs. The Rural Pension program has two main components: (i) the noncontributory program (or the "solidarity" component), a basic pension in the form of a basic fixed benefit that is paid by the government; and (ii) an

\footnotetext{
2 This program replaced the Old Rural Pension Scheme, which aimed to be a fully funded defined contribution plan, but its growth stagnated in 1998 (Lei et al. 2015)
} 
individual pension component, financed by the individual's own contributions but "topped-off" by government subsidies (with contributions to the subsidy from both the central and local governments). Members contribute annually, choosing the level of contribution from a range of CNY100 to CNY2,000. The initial value of the basic pension under the scheme is CNY70 per month (about \$20 USD-PPP of 2017), supplemented by the individual pension component and possibly topped up by local governments at their discretion from their own revenues. Fifteen years of contribution to the system are required in order to become eligible for the pension.

The noncontributory component of the Rural Pension makes it very attractive to potential contributors younger than 60. To make participation strongly desirable for those older than 60 , the program gives them the flat CNY70 amount as long as the individual either makes a lumpsum contribution or, if they have children, they apply for a family-binding policy that allows them to qualify if their working-age child makes their contribution (World Bank 2016b). With this rule, the program incentivizes participation of both the parent and the child.

\section{Protection against unemployment and disability}

China has an unemployment insurance (UI) scheme, in which both employers and employees contribute a percentage of their wages ( 1 percent and 2 percent respectively). Upon unemployment, the contributor receives a payment that varies by state, but lies between the local dibao (the minimum level of standard of living guaranteed by governments) and the minimum wage (ILO 2018).

\subsection{Mexico}

IMSS, ISSSTE, and the traditional social security system

The Instituto Mexicano del Seguro Social (IMSS) and the Instituto de Seguridady Servicios Sociales de los Trabajadores del Estado (ISSSTE) are the two pillars that provide social security in health, disability, and pensions to workers or retirees of the private and public 
sector, respectively. Though they have grown in size and in the proportion of the population that they cover since their founding in 1943 and 1959 respectively, they have always covered only a minority of the population because more than half of workers are informally employed.

IMSS and ISSSTE reformed their pension systems from traditional pay-as-you-go (PAYG) programs to fully funded with personal retirement accounts (PRA) in July 1997 and April 2007, respectively. In both cases, the minimum years of contribution for eligibility to receive pension benefits is 10 years (500 weeks) and there is a minimum pension guarantee (MPG) based on the minimum wage of Mexico City. Moving across IMSS and ISSSTE is not possible. Under both the PRA and PAYG systems, normal retirement is 65 years of age, but early retirement is also possible after age 60 . With the personal retirement accounts, individuals can contribute even when not working, and their contributions count even outside the system, but the minimum contribution requirement is 25 years. In the PAYG, the early retirement pension benefits are reduced for each year that one retires earlier than the normal retirement age. In the PRA, early retirement is not explicitly penalized because individuals receive pension benefits according to the amount accumulated in the personal retirement account. Under the new PRA system, early retirement is available for those who can obtain a pension equivalent to 130 percent of the minimum wage of Mexico City, which is the MPG. Individuals who do not satisfy the minimum years of contribution in the PRA system can withdraw the amount accumulated in the individual account, but they cannot claim the MPG (Aguila et al. 2011).

\section{Noncontributory pension programs}

In 2007, the Mexican government established a non-contributory pension program for individuals 70 years or older in rural localities with less than 2,500 inhabitants. The Programa de Atención a los Adultos Mayores de 70 años y más en zonas rurales (PAAM) provided a monthly pension of MXN500 or US\$82.2 PPP (SEDESOL 2007). The program expanded in 2008 to all 
localities with less than 20,000 inhabitants; in 2009, it expanded to all localities with less than 30,000 inhabitants (SEDESOL 2008, 2009) and was renamed to Programa 70 y Más (70 y Más) in 2009. In 2012, it expanded to all urban and rural localities in the country but excluded adults receiving any other social security benefits (SEDESOL 2012).

In 2013, the age requirement for the program decreased from 70 to 65 years old (Aguila et al. 2013) and the program was renamed Programa Pensión para Adultos Mayores (PPAM). The monthly cash transfer set in 2007 remained unchanged until 2013, when it increased 5 percent to MXN525 (USD 67.0 PPP). In 2014, the program started including individuals who receive social security benefits of less than MXN1,092 per month and the monthly amount of the pension increased to MXN580 (USD73.3 PPP of $2017^{3}$ ) (SEDESOL 2014).

\subsection{India}

There are a large number of public pension and social security programs in India. Some are programs of the central government and others are programs of state governments. SSA (2017) lists programs and their characteristics.

India's central government reformed its formal pension system by creating the National Pension System (NPS), which is a defined contribution (DC) plan that replaced the defined benefit (DB) payments to which federal government employees were entitled. An extensive discussion of this reform is given in Shah (2006). Through this program, participation of central government employees joining after 2004 is mandatory. State government employees and state autonomous body employees also are mandated to participate if they joined after an initial date that varies across states. Thus, some current and former government employees are still enrolled in the previous DB plan, whereas others are enrolled in the NPS.

\footnotetext{
${ }^{3}$ https://data.oecd.org/conversion/purchasing-power-parities-ppp.htm
} 
Private sector employers can choose to provide their employees with pension benefits through the NPS corporate branch. Federal employees who had joined before, as well as nonfederal employees and every citizen between the ages of 18 and 60 can join the program on a voluntary basis. Furthermore, to encourage participation, the government added a contribution of INR 1,000 per year ${ }^{4}$ between 2010 and 2017 to each eligible NPS enrollee who contributed a minimum of INR 1,000 and maximum of INR 12,000 per year. However, it is still the case that the bulk of NPS participants are the federal employees whose participation is mandatory. By 2016, about 35 percent of the 14.1 million participants were government employees, but they accounted for close to 90 percent of the investment funds, suggesting the contributions of the voluntary enrollees were on average much lower (Economic Times 2017).

Members of the NPS who are mandated to participate contribute 10 percent of their salary (plus a 10 percent contribution from the government) to the scheme. Withdrawals can occur upon retirement or resignation. If retirement, the member is required to invest at least 40 percent in an annuity approved by the regulatory authority; whereas upon resignation, the member is required to invest at least 80 percent in such an annuity.

Though important, the NPS leaves the vast majority of the population uncovered, with particularly dire consequences for the poor. Thus, social assistance programs to support the elderly have been launched by both central and state governments. The largest program was launched by the central government: The Indira Gandhi National Old Age Pension Scheme (IGNOAPS) aimed to provide INR200 monthly for individuals older than 65 in poor households (Bloom et al., 2010). By current rules, individuals between ages 60 and 80 who live below the national poverty line are entitled to INR300 per month, and those older than 80 are entitled to

\footnotetext{
${ }^{4}$ In 2017, INR. 17.767 was about equal to US\$ 1, purchasing power parity (PPP) adjusted, according to the OECD https://data.oecd.org/conversion/purchasing-power-parities-ppp.htm. Hence, INR. 1,000 is approximately equal to $\$ 56$.
} 
INR500. The IGNOAPS is part of the National Social Assistance Program that also includes the Indira Gandhi National Widow Scheme and the Indira Gandhi National Disability Pension Scheme. These operate in a similar manner as the IGNOAPS, and they provide, respectively, a monthly payment of INR200 for widows younger than 60 (since later they are eligible for the pension part) and INR300 for individuals younger than 60 with a work limiting disability, in both cases subject to be living below the poverty line.

The public pension landscape becomes more complex beyond the central government, as states are allowed, and indeed encouraged, to top off the national pension program beyond the INR 100 per month that they are required to contribute. Furthermore, some states choose to relax the limitation of providing it to those living under the poverty line, and provide it to wider groups. In Delhi, for example, the monthly amount is INR1,000, and it is available to a much larger fraction of the residents. Other states do not expand the coverage of the IGNOAPS, but have established parallel programs that cover families not supported by IGNOAPS.

In addition, recently developed "micro pension" schemes have arisen (Bloom et al. 2010; Shankar, and Asher, 2011). These are mostly based on private contributions, but some are supported by state level governments.

\section{Data and methodology}

\section{Data}

We use data from the international family of Health and Retirement studies (HRS). Specifically, we use the Mexican Health and Aging Study (MHAS), and the China Health, Aging, and Retirement Longitudinal Study (CHARLS).

One of the advantages of using these data is that despite the large differences in the background of these countries, the questionnaires of these studies are highly comparable. Furthermore, the research team at the Gateway to Global Aging Data (g2aging.org) has done an 
important work in harmonizing data with consistent variable names and definitions that are constructed and made available at the Gateway to Global Aging Data. This allows us to do parallel analysis in the three countries and to make comparisons across them.

The questionnaires all ask whether individuals are currently receiving social security benefits, and if not, whether they are eligible for future social security benefits. Hence, we are able to estimate the fraction of the covered population, broken down by relevant variables. Further, the data contain information about demographics, education, employment, income, and wealth that we can use for breakdowns and modeling. For our purposes, an important aspect of the surveys in the HRS family is that they contain a detailed labor force module and an income module. Often, many of the data sets used for social security studies are labor force studies that contain detailed labor force modules but not detailed income data. The labor force module provides variables including contribution to pension and social security programs, benefits, among others needed to predict who will be eligible for pension benefits or social security. But many of the newer social security programs are not intrinsically linked to employment; and whether an individual is part of these programs is often not asked in the labor force module but in the income module, where the questionnaires ask about receipt of benefits from different government programs.

For the case of China and Mexico, the panel nature of the surveys in the HRS family allows to compare not only the current stage of the two countries, but also their trajectories. We use all the existing waves of the surveys. For China, we use three waves of CHARLS, corresponding to years 2011, 2013 and 2015. Though it spans a relatively short five-year period, it is a time of stunning transformation that we are able to analyze. For Mexico, we use three waves for MHAS 2001, 2003, and 2012, which also captures a period of important transformations in Mexico's social policy. Finally, we will update this analysis to include data from India when the on-going data collection is completed and the LASI data is publicly 
released. Furthermore, we hope our research is used as a platform to comparatively study the progress in these three countries when future waves are added in each of these countries.

Sample

Our main sample consists of every survey respondent 45 and older. However, we focus on different subsamples for different aspects of the analysis. For social security pension coverage, we only consider individuals 64 and older for the three countries analyzed. To build the new cohort of future pension beneficiaries for the counterfactual scenarios, we focus on individuals ages 45 to 64 .

Table 3.1.1.a shows the gender composition of the samples in CHARLS wave 4 (left) and MHAS wave 3 (right) by age group for respondents 45 and older. Table 3.1.1.b shows the levels of urban/rural hukou for China and residency for Mexico.

Table 3.1.1.a: Sample composition for CHARLS and MHAS, by age and gender

\begin{tabular}{lcccccc} 
& \multicolumn{3}{c}{ China (CHARLS) } & \multicolumn{3}{c}{ Mexico (MHAS) } \\
Age group & Male & Female & Total & Male & Female & Total \\
\hline $\mathbf{4 5 - 4 9}$ & 1,275 & 1,426 & 2,701 & 129 & 455 & 584 \\
$\mathbf{5 0 - 5 4}$ & 1,709 & 1,881 & 3,590 & 972 & 1,361 & 2,333 \\
$\mathbf{5 5 - 5 9}$ & 1,513 & 1,532 & 3,045 & 881 & 1,550 & 2,431 \\
$\mathbf{6 0 - 6 4}$ & 1,734 & 1,873 & 3,607 & 1,220 & 1,459 & 2,679 \\
$\mathbf{6 5 - 6 9}$ & 1,320 & 1,285 & 2,605 & 1,213 & 1,325 & 2,538 \\
$\mathbf{7 0 +}$ & 1,838 & 1,890 & 3,728 & 2,169 & 2,639 & 4,808 \\
Total & 9,389 & 9,887 & 19,276 & 6,584 & 8,789 & 15,373
\end{tabular}

Table 3.1.1b: Sample composition for CHARLS and MHAS, by urbanicity

\begin{tabular}{llll} 
& \multicolumn{2}{c}{ China } & \multicolumn{1}{c}{ Mexico } \\
\hline Urban & & & \\
hukou & 4,246 & Urban community & 12,277 \\
Rural hukou & 14,014 & Rural village & 3,011 \\
Total & 18,260 & Total & 15,288
\end{tabular}




\subsection{Methodology}

By using the relevant survey weights, we obtain representative estimates of the proportions of the population covered by social security programs, as well as the level of benefits enjoyed by those groups. We use these estimates to make comparisons across:

- Population groups of interests: In particular, we look at gender, urban or rural status, education groups, etc.

- Time: We use the available survey waves to analyze trends at the national and subgroup of interest level, to see how changing conditions have affected patterns.

- Countries: We compare levels in the most recent waves across the three countries. In the case of China and Mexico, we also compare the trends in the variables of interests over time.

In addition to the use of cross tabulations, we also run regression models to estimate the contribution of a number of variables on the outcomes of interest. For this purpose, we developed and estimated models of determinants of social security coverage and pension income from public programs, which we will use for projections and static comparative analyses. The predictors in these models fall in the following categories: demographics (gender, age, marital status, rural/urban status, rural/urban residency), educational attainment, and work history (ever worked/age of first job, proxies for formal sector, tenure, full/part time, hours worked, selfemployment, earnings).

First, we estimated cross-sectional models of current social security pension coverage and pension income which can be used for the three countries. Second, we estimated models of current social security pension coverage and pension income using lagged variables, exploiting the panel dimension of the data. Lastly, we estimated a model of eligibility for future social security pension coverage for current workers.

Social security coverage is defined as receiving public pensions. The models for coverage estimate the probability of receiving public pensions using a logit regression on the subsample 
ages 65 and older. For the estimations of pension income, we used linear regressions on the 65

and older subsample. We estimate public pension eligibility using logit models and the sample of 45 and older. To estimate the probability of receiving income from other government programs, we use logit regressions on the sample 45 and older.

We ran several specifications to account for all factors affecting each variable of interest. Each cross-sectional specification estimates the outcome of interest as a function of a subset of the following set of regressors and relevant interactions: an age polynomial, gender, marital status, educational attainment, an indicator of whether the individual ever worked, age of first work, years in the labor force before retiring, earnings, whether rural or urban hukou registration (for China), whether urban or rural household.

Each model using the panel dimension of the data (for China and Mexico only) estimate the outcome of interest as a function of a subset of the following regressors and relevant interactions: a second order polynomial on age, gender, marital status, educational attainment, current and lagged values of whether rural or urban hukou (for China), current and lagged values of whether urban or rural household, an indicator of whether the person has ever worked, age of first work, lagged values of average hours worked, lagged values of self-employment indicators, lagged values of whether the person worked mainly part- or full-time, years in the labor force before retiring, current and lagged values of earnings, past indicators of public pension eligibility.

\section{Who is covered and not covered by social security programs?}

China, Mexico, and India have experienced important transformations in terms of their social security coverage in the last few decades. In some aspects, they have experienced very different trends, as expected given their very different starting points and very different growth trajectories in the $2000 \mathrm{~s}$. 
While China's economy has seen unprecedented growth in the last two decades with its per capita GDP growing an average of 8.5 percent per year, Mexico's economy and formal sector have comparatively slower growth at almost 1 percent per year on average. Despite this, they share commonalities in the changes taking place in their social security systems, albeit important differences, too. In China, the coverage of social security has grown in parallel with the economy. Mexico has seen mostly stable levels in the share of employment in formal sector and in the coverage rates of their contributory pension programs.

China, Mexico, and India have expanded or created new programs to extend coverage. They have transformed from only having in place pension systems with broad coverage for employees in certain sectors (formal sector in Mexico, salaried workers and civil servants in China and India), and are moving toward a situation where almost all above a certain age have some coverage. China created the Rural Pension scheme in 2012, Mexico created the 70 y Mas (later PPAM) that originally covered everybody older than 70 in small rural towns, but currently is expanding to cover everyone. India created and expanded the IGNOAPS to cover those older than 60 who live under the poverty line (and the related programs for widows and disabled).

These changes have resulted in increased coverage. Figure 4.0.1 shows the coverage rates in the first and last waves available in the harmonized data for Mexico and China. The coverage rates have increased dramatically in Mexico and China. 
Figure 4.0.1 Effective Coverage of Old Age Pensions. 70+ year olds who are pension beneficiaries.

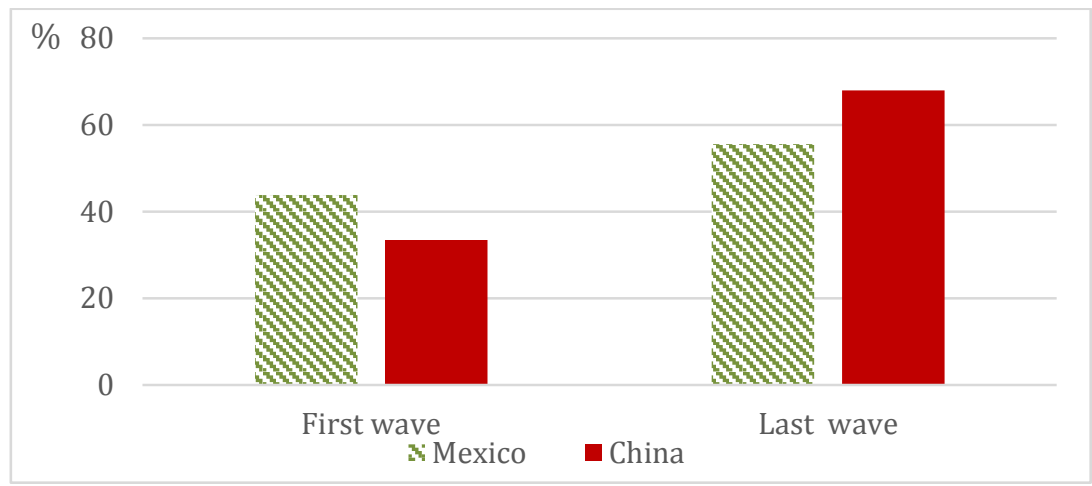

Note: The graph shows percentage of those 70 and older receiving a pension program. The last wave of data for Mexico corresponds to 2012, for China it corresponds to 2015. In the case of Mexico, the share receiving a pension includes individuals who receive benefits from the PPAM, even though the harmonized variable available in MHAS does not include pensions from this program.

In what follows we describe these patterns, and use data form CHARLS and MHAS to help elucidate what these patterns have meant for these countries' populations. Most of our focus is on analyzing coverage in old age, where the transformation has been most dramatic. When relevant and possible, we also describe other aspects of social security, including unemployment insurance, and disability.

First, we investigate what population is covered by social security programs in China, Mexico, and how that has changed in recent years. We compute the overall fraction of the population that is covered, and where relevant split this by type of social security program and by whether individuals are currently receiving benefits or expect to receive them in the future. We compute these statistics also separately by urbanicity, which is strongly related to social and economic outcomes in developing countries. We then break down our results by likely determinants or correlates of coverage: demographic correlates such as age, gender, marital 
status, and educational attainment; and labor force status and history, such as whether individual worked in earlier years, whether she worked in the formal sector, age at first employment, etc.

\subsection{China}

We analyze the CHARLS data to describe the covered and uncovered populations. By 2015, a majority of adults older than 60 received a pension: 71.5 percent of those in the 60 to 69 age range and 74.2 percent among those older than 70. Figure 4.1.1 shows that the fraction of population covered by public pensions is substantially higher in 2015 than in 2011 . The growth in coverage is remarkable even in the context of rapid economic growth, and it can be explained by the rapid expansion of the social security program landscape in China. These numbers show that China is on trend towards the universal coverage, which is a goal the government set for 2020 (Giles et al. 2013).

Figure 4.1.1 Recipients of public pensions, fraction, by age group, China

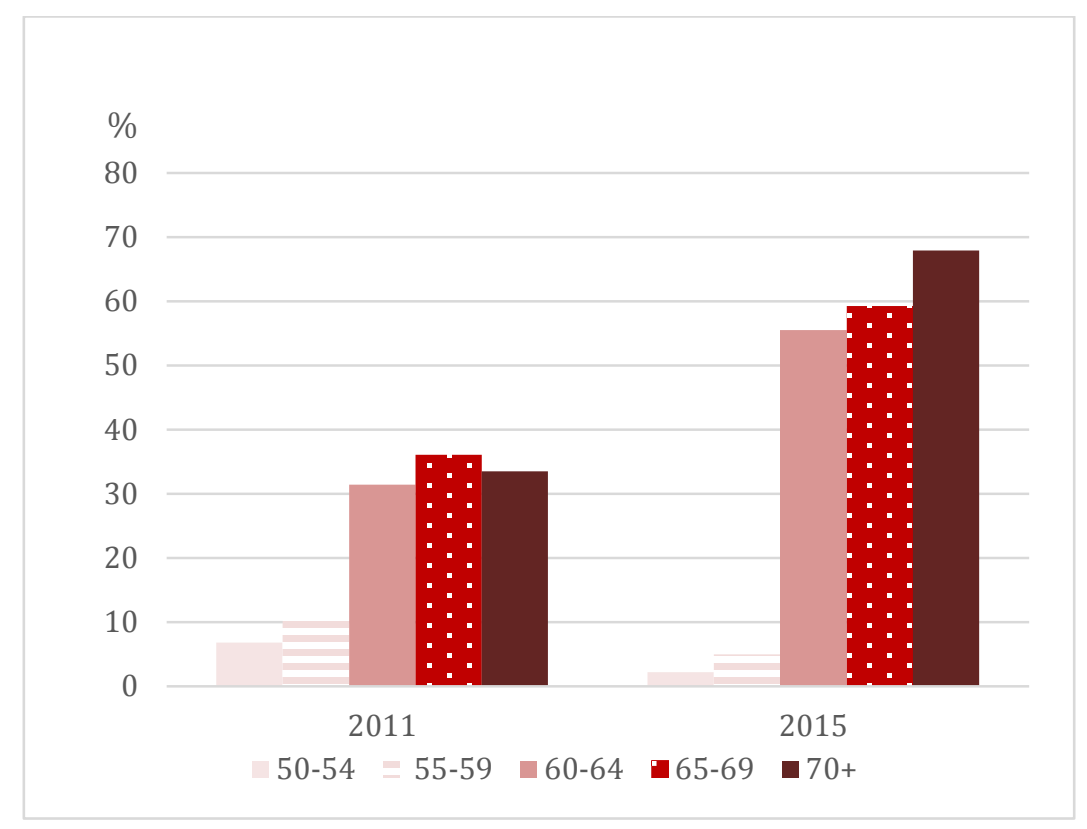

Source: CHARLS, waves 1 and 4.

The growth in coverage had large effects on the characteristics of the covered population. Table 4.1.1 shows the composition of those receiving public pension 65 and older. There are 
several changes to note. At baseline, in 2011, there was no gender difference in the proportion covered: 34.5 percent of both male and female adults older than 65 were receiving benefits. The proportion among both genders increased, but the increase was larger among women: By 2015, the proportion receiving a public pension was 7 percentage points larger among women. The fact that the increase was larger among women is likely a result that the new programs benefit those outside government and enterprise employment, where more men work.

The pattern is more remarkable among education levels. There was a small positive education gradient in 2011, when Chinese elders with tertiary education were 5 percentage points and 3 percentage points more likely to be a public pension recipient than those with upper secondary and those with lower secondary and below, respectively. The gradient had completely reversed by 2015: Those with the least education were now twice as likely of being a public pension recipient as those with upper secondary education or higher.

Those with an urban hukou were more likely to receive a public pension in 2011 , since having an urban hukou is helpful in order to secure a formal or government job or a job in the bureaucracy (Liu 2005), which were the jobs covered by the SIIAO for urban enterprise workers, and for government and civil servants. By 2015, the coverage rate among those with an urban hukou had slightly declined, whereas the corresponding proportion among those with a rural hukou had more than doubled. These patterns can be explained by the introduction and quick expansion of the Rural Pension program.

As an aside note, the reader may be surprised to see a decline (albeit small) in the coverage among some groups, such as those with tertiary education. This is likely a result of more people receiving income from individual contribution programs not catalogued as public programs. As discussed in the Background section, some of the defined benefit programs became defined contribution, and some people who may have earlier declared to be receiving a public pension may now not be doing so in the most recent waves. That does not necessarily mean, however, a 
reduction in their income stream. This becomes clearer in the text below when we discuss the pension benefit amounts.

The expansion of the Rural Pension can be appreciated in the rapid growth of public pension receipt among the rural sector, both among those who live in rural areas and among those who live in urban areas but have a rural hukou. The Rural Pension program was targeted to both rural residents and "nonsalaried" urban residents, who are often individuals living in cities but who cannot obtain a formal, salaried position because they have a rural hukou. The percentage of public pension recipients among both those who live in a rural area and among those who have a rural hukou (but may or may not live in a rural area) increased steeply from about 33 percent to 75 percent and 77 percent respectively. It also increased significantly among those living in urban areas (with or without an urban hukou), from 37 percent to about 51 percent, but it did not increase among those with an urban hukou. These results are more consistent with the entirety of the coverage growth being attributable to the rollout of the Rural Pension than to other factors such as economic growth. 
Table 4.1.1: Recipients of public pension in China, percentages (65 and older)

\begin{tabular}{r|ll} 
Year & $\mathbf{2 0 1 1}$ & $\mathbf{2 0 1 5}$ \\
Male & 34.4 & 61 \\
Female & 34.5 & 67.9 \\
& & \\
Less than lower secondary educ. & 34.3 & 67.6 \\
Upper secondary \& vocational training & 36.2 & 33.6 \\
Tertiary educ. & 39 & 18 \\
Never married & 45.9 & 64.4 \\
Married & 36.6 & 61.4 \\
Partnered/separated/divorced/widowed & 30.4 & 70.8 \\
Urban hukou & 39.5 & 33.4 \\
Rural hukou & 32.8 & 76.6 \\
Urban community & 36.8 & 51.2 \\
Rural village & 32.8 & 74.6
\end{tabular}

Note: Percentage of individuals 65 and older receiving income from a public pension. Source: CHARLS waves 1 and 4 .

Table 4.1.2 shows average pension income in 2015 among those who do receive a pension, and by subpopulation groups. Despite the reversal of the coverage correlates described in Table 4.1.1, where it became the case that characteristics typically associated with positive economic outcomes became negative predictors of having a pension, these characteristics still remain positive predictors of the pension amount.

Average pension receipt is highest among the more educated: It is about CNY35,000 for those with higher education, compared to CNY30,000 for those with upper secondary education and CNY6,000 for those without an education. On average, male retirees have higher pensions than females (CNY11,700 versus CNY6,400). The difference between those with a rural and urban hukou are very large: those with an urban hukou receive about CNY20,000 while those with a rural hukou get CNY1,400. 
The yearly average amount of CNY1,400 for those with a rural hukou is less than double the yearly basic contribution that the central government provides as the "solidarity component" of CNY70 per month. This reflects the fact that a large fraction of those with a rural hukou are receiving only the solidarity component.

Table 4.1.2: Mean public pension income in China by demographic characteristic

\begin{tabular}{ll}
\hline Total pension income if retired, 2015 & $\begin{array}{l}\text { Mean } \\
\text { (in 2010 CNY) }\end{array}$ \\
\hline All & $8,882.10$ \\
Male & $12,310.80$ \\
Female & $5,846.00$ \\
Less than lower secondary educ. & $5,830.60$ \\
Upper secondary \& vocational training & $29,723.00$ \\
Tertiary educ. & $35,434.50$ \\
& \\
Age 65-69 & $10,382.30$ \\
Age 70+ & $8,143.50$ \\
Never married & $1,523.60$ \\
Married & $10,241.60$ \\
Partnered/separated/divorced/widowed & $6,661.00$ \\
Urban hukou & $19,817.20$ \\
Rural hukou & $1,406.20$ \\
\hline
\end{tabular}

Note: Average annual pension amount received among those receiving any amount, age 65 and older. Pension amounts are deflated to 2010 CNYusing the annual consumer price index provided by the OECD Consumer Price (MEI) dataset. Source: CHARLS wave 4.

These findings reflect the evolution of the social security landscape over recent years. The introduction of the Rural Pension reached a large proportion of people, mostly with lower levels of education and a rural hukou. But this program provides much lower benefits than other 
pension programs. This is particularly so for the first entrants to the program since, as described in the Background section, they only get access to the noncontributory part of the program (currently CNY70 per month, or about \$20 USD-PPP at 2017 prices).

Individuals can be covered for old-age pensions, as well as spousal benefits or disability, and one does not logically imply the other. Hence, they merit separate attention. The number of disability or unemployment benefits recipients is too low for us to show their correlates with any confidence in their statistical power. According to the ILO (2018), 18.8 percent of the unemployed received benefits in China in 2015, all of them from a contributory program. Since the unemployment rate is low $\left(4.08\right.$ percent in $\left.2015^{5}\right)$, the total proportion of respondents who were receiving unemployment benefits would be expected to be too low to be captured with statistical precision in a survey with sample sizes like the ones we use. Disability rates are also low. According to our estimates, less than 2 percent of men and women reported to be disabled in 2015 .

We analyze the population receiving benefits from all other social programs combined. Table 4.1.3 shows the fraction reporting to have received "other government transfers." There is important growth in this fraction, particularly among groups such as the one composed of individuals with tertiary education, who are the group most likely to be a recipient in 2015 . $^{6}$

The changes over time in the characteristics of pension recipients do not all carry over to explaining receipt of transfers of other programs either. There are no large differences in government transfers recipiency by gender either in 2011 or 2015.

\footnotetext{
${ }^{5}$ World Bank Data https://data.worldbank.org/

${ }^{6}$ This reflects in part the change of some individuals who before reported "public pension" and are now being reported in "other government transfers" which in turn explains the slight decline in public pension described for that group under the discussion of Table 4.1.1.
} 
Table 4.1.3: Recipients of other government transfers in China. Percentage, 45 and older

\begin{tabular}{l|ll}
\hline & \multicolumn{2}{|c}{$\begin{array}{c}\text { Other Government } \\
\text { Transfers }\end{array}$} \\
\hline Year & \multicolumn{2}{|c}{2011} \\
Male & 7.3 & 17 \\
Female & 6 & 16.3 \\
& & \\
Less than lower secondary education & 6.6 & 16.7 \\
Upper secondary \& vocational training & 7 & 14.4 \\
Tertiary education & 5.5 & 22 \\
& & \\
Age 45-49 & 4.7 & 11.6 \\
Age 50-59 & 4.6 & 10.25 \\
Age 60-69 & 6.5 & 13.75 \\
Age 70+ & 13.3 & 13.3 \\
Never married & & \\
Married & 20.2 & 38.2 \\
Partnered/separated/divorced/widowed & 10.4 & 13.6 \\
& & 28.2 \\
Urban hukou & 8.2 & 19.4 \\
Rural hukou & 5.9 & 15.8 \\
Urban community & & \\
Rural village & 7.8 & 19.0 \\
\hline & 5.9 & 14.9 \\
\hline
\end{tabular}

\section{Regression models}

A more comprehensive way to show how the characteristics of the covered population have changed is to analyze the correlates in a regression model. Table 4.1.4 shows regressions using data from each of the three waves. In the first wave for China, being a pensioner was positively predicted by variables such as an indicator of having tertiary education and an urban hukou, which tend to be indicators of high socioeconomic status. Only two years later, by the second wave, (see column 2) this relationship had reversed, with the coefficients for those same 
variables becoming negative and statistically significant. This negative relationship remains and strengthens when using the data from the most recent wave. ${ }^{7}$

Columns 4 and 5 shows the estimation results for annual pension income amount (deflated to 2010 prices for cross-round comparability). Contrary to what occurs with the coverage outcomes, the estimated coefficients are more stable across survey waves. In all cases, education is strongly and positively correlated with the pension amount, and in all waves the coefficient is close to CNY20,000, with a small reduction across waves. Likewise, the rural hukou dummy is always negative and strongly significant. It is worth noting that there is a premium for high school education, but it mostly disappears in 2015 for those with a rural hukou, as the interaction between high school education and rural hukou almost equals the size of the high school premium.

Column 6 presents the results of a logit model where the dependent variable is an indicator of whether the individual is enrolled in a public pension program, which serves as a proxy for whether they will be eligible for social security pension benefits at retirement. In this case, the sample is composed of adults 45 or older. As in the case of pension income amount, the variables correlated with better labor force outcomes (higher education levels, urban hukou and male) have a positive and statistically significant coefficient. This is because those who are working are contributing to the traditional pension programs such as the SIIAO rather than relying only on the noncontributory aspect of the Rural Pension.

\footnotetext{
${ }^{7}$ For robustness, we also ran specifications controling for additional interactions and work history variables, such as age of first-time work. However, the results are not sensitive to these variations. These tables, not presented here for simplicity and to save space, are available upon request.
} 
Table 4.1.4. Cross-sectional Regression Models of Social Security Benefit Receipt and Eligibility, China.

\begin{tabular}{|c|c|c|c|c|c|c|c|}
\hline & \multicolumn{3}{|c|}{ Pension Coverage } & \multicolumn{2}{|c|}{ Pension Income } & \multirow{2}{*}{$\begin{array}{c}\text { Pension } \\
\text { Eligibility } \\
2015\end{array}$} & \multirow{2}{*}{$\begin{array}{c}\text { Other Govt. } \\
\text { Transfers } \\
2015\end{array}$} \\
\hline & 2011 & 2013 & 2015 & 2011 & 2015 & & \\
\hline \multirow[t]{2}{*}{ Age group } & $65+$ & $65+$ & $65+$ & $65+$ & $65+$ & $45+$ & $45+$ \\
\hline & (1) & $(2)$ & (3) & (4) & (5) & (6) & $(7)$ \\
\hline Regressor & \multicolumn{3}{|c|}{$\begin{array}{l}\text { Average marginal effects from } \\
\text { logit regression }\end{array}$} & \multicolumn{2}{|c|}{$\begin{array}{l}\text { Coefficients from linear } \\
\text { regression }\end{array}$} & \multicolumn{2}{|c|}{$\begin{array}{l}\text { Average marginal effects } \\
\text { from logit regression }\end{array}$} \\
\hline Age & $\begin{array}{l}0.001 \\
(0.002)\end{array}$ & $\begin{array}{l}0.004^{\star * *} \\
(0.002)\end{array}$ & $\begin{array}{l}0.011^{* * *} \\
(0.002)\end{array}$ & $\begin{array}{l}-450.600 \\
(807.639)\end{array}$ & $\begin{array}{l}-135.924 \\
(469.278)\end{array}$ & $\begin{array}{l}0.241 \\
(0.235)\end{array}$ & $\begin{array}{l}0.015^{\star * *} \\
(0.001)\end{array}$ \\
\hline Female & $\begin{array}{l}0.002 \\
(0.024)\end{array}$ & $\begin{array}{l}0.042^{* *} \\
(0.021)\end{array}$ & $\begin{array}{l}0.043^{* *} \\
(0.020)\end{array}$ & $\begin{array}{l}1,614.021^{* *} \\
(755.045)\end{array}$ & $\begin{array}{l}243.973 \\
(675.483)\end{array}$ & $\begin{array}{l}0.800 \\
(0.611)\end{array}$ & $\begin{array}{l}-0.025 \\
(0.018)\end{array}$ \\
\hline Married & $\begin{array}{l}-0.097 \\
(0.111)\end{array}$ & $\begin{array}{l}0.006 \\
(0.072)\end{array}$ & $\begin{array}{l}0.057 \\
(0.080)\end{array}$ & $\begin{array}{l}3,062.652^{\star \star \star} \\
(838.849)\end{array}$ & $\begin{array}{l}2,498.920^{* * *} \\
(731.702)\end{array}$ & $\begin{array}{l}0.207 \\
(0.371)\end{array}$ & $\begin{array}{l}-0.358^{*} \\
(0.190)\end{array}$ \\
\hline \multirow[t]{2}{*}{$\begin{array}{l}\text { Partnered/separate } \\
\text { d/ } \\
\text { divorced/widowed }\end{array}$} & -0.160 & 0.022 & 0.058 & $2,431.661^{* *}$ & $1,517.933^{*}$ & & $-0.333^{*}$ \\
\hline & $(0.113)$ & $(0.075)$ & $(0.082)$ & $(973.168)$ & (837.354) & & (0.191) \\
\hline Female \& Married & & & $\begin{array}{l}-0.164^{* * *} \\
(0.058)\end{array}$ & $\begin{array}{l}-3,741.720^{\star * *} \\
(1,010.686)\end{array}$ & $\begin{array}{l}-1,090.295 \\
(881.446)\end{array}$ & $\begin{array}{l}-1.916^{* \star *} \\
(0.651)\end{array}$ & \\
\hline Female \& & & & $-0.440^{* * *}$ & $-4,741.985^{\star * *}$ & $-1,907.444^{* *}$ & & \\
\hline \multicolumn{8}{|l|}{ Part/Div/Widow } \\
\hline \multirow[t]{2}{*}{$\begin{array}{l}\text { Upper secondary \& } \\
\text { vocational training }\end{array}$} & -0.031 & $-0.133^{* *}$ & $-0.164^{* * *}$ & $12,623.066^{\star * *}$ & $10,235.453^{\star * *}$ & $0.550^{*}$ & -0.042 \\
\hline & $(0.064)$ & $(0.060)$ & $(0.058)$ & $(2,246.938)$ & $(2,233.449)$ & $(0.298)$ & $(0.045)$ \\
\hline Tertiary educ. & $\begin{array}{l}0.040 \\
(0.237)\end{array}$ & $\begin{array}{l}-0.191 \\
(0.222)\end{array}$ & $\begin{array}{l}-0.440^{* * *} \\
(0.130)\end{array}$ & $\begin{array}{l}21,285.191^{* * *} \\
(3,859.807)\end{array}$ & $\begin{array}{l}19,427.044^{* * *} \\
(3,331.406)\end{array}$ & $\begin{array}{l}1.300^{* * *} \\
(0.374)\end{array}$ & $\begin{array}{l}0.147 \\
(0.172)\end{array}$ \\
\hline \multirow[t]{2}{*}{ Rural hukou } & $-0.062^{*}$ & $0.452^{* * *}$ & $0.380^{* * *}$ & $-15,759.648^{\star * *}$ & $12,509.160^{\star \star *}$ & 0.012 & 0.003 \\
\hline & $(0.037)$ & $(0.031)$ & $(0.031)$ & $(1,037.687)$ & $(807.494)$ & $(0.296)$ & $(0.025)$ \\
\hline Rural household & $\begin{array}{l}-0.032 \\
(0.026)\end{array}$ & $\begin{array}{l}0.051^{* * *} \\
(0.019)\end{array}$ & $\begin{array}{l}0.036^{\star \star} \\
(0.018)\end{array}$ & & & $\begin{array}{l}0.412 \\
(0.267)\end{array}$ & $\begin{array}{l}-0.011 \\
(0.017)\end{array}$ \\
\hline \multirow[t]{2}{*}{$\begin{array}{l}\text { Rural hukou \& } \\
\text { Secondary educ. }\end{array}$} & & & & $-7,639.260^{\star * *}$ & $-9,155.320^{\star * *}$ & & \\
\hline & & & & $(2,918.009)$ & $(2,447.477)$ & & \\
\hline Rural hukou \& & & & & $-12,872.470$ & $-2,037.905$ & & \\
\hline Tertiary educ. & & & & $(8,057.330)$ & $(5,886.285)$ & & \\
\hline \multirow[t]{2}{*}{$\begin{array}{l}\text { Ever worked for } \\
\text { pay }\end{array}$} & 0.164 & 0.130 & $0.204^{* * *}$ & $6,373.313^{* *}$ & $6,495.972^{\star * *}$ & & 0.063 \\
\hline & $(0.143)$ & $(0.080)$ & $(0.076)$ & $(2,505.402)$ & $(1,958.391)$ & & $(0.090)$ \\
\hline Earnings (log) & & & & & & $\begin{array}{l}0.081^{* * *} \\
(0.026)\end{array}$ & $\begin{array}{l}0.005^{*} \\
(0.003)\end{array}$ \\
\hline Interaction female & Y & & & & & & $\mathrm{Y}$ \\
\hline
\end{tabular}




\begin{tabular}{|c|c|c|c|c|c|c|c|}
\hline $\begin{array}{l}\mathrm{x} \text { education } \\
\text { Interaction rural } \mathrm{x} \\
\text { education }\end{array}$ & Y & & & & & & Y \\
\hline Constant & & & & $\begin{array}{l}21,746.650 \\
(30,082.890)\end{array}$ & $\begin{array}{l}10,318.916 \\
(17,895.447)\end{array}$ & $\begin{array}{l}-8.245 \\
(6.583)\end{array}$ & \\
\hline Observations & 3,575 & 4,747 & 5,440 & 3,358 & 3,847 & 740 & 4,968 \\
\hline
\end{tabular}

Robust standard errors in parentheses. ${ }^{* * *} p<0.01,{ }^{* *} p<0.05,{ }^{*} p<0.1$ Note: All regression models include a second order polynomial on age.

An advantage of using the CHARLS data is that we can exploit the panel data aspect to analyze individuals' transitions across survey waves. As described in the methodology subsection (3.2), we regress the outcome variable of interest in the last wave (public pension coverage and pension amount) against a set of labor market and demographic variables measured both contemporaneously and in the prior waves. In particular, this allows us to estimate the effect of labor force status in 2011 and 2013 on individuals 65 and older in 2015.

Table 4.1.5 shows these results using two specifications. Column 1 controls for an indicator of whether the individual has ever worked for pay, and Column 2 shows the results, including a rich set of work history variables: average hours worked, part-time versus full-time work, and self-employment status. In the case of pension coverage, few variables are strongly significant. The female dummy has a positive and significant coefficient, as does working in wave 1. However, most of the labor force status variables do not have much explanatory power. This is consistent with the "decoupling" of the labor history and pension accrual that we have described using the static models. One exception is that those who have ever worked and those who started working at younger ages are more likely to receive public pensions.

Also, consistent with the results above are the results, shown in Column 3 of Table 4.1.5, that correspond to a linear regression of the income amount against the set of variables from the contemporaneous and prior waves. Here, the labor market variables are of the expected signs, with having worked part-time or as self-employed negatively predicting pension income. The 
education dummies are positive, and having tertiary education is associated with CNY32,000 more per year in pension income. Currently having or having had in the past a rural hukou negatively predicts pension income.

Overall, these results show that some characteristics formerly associated with receiving a pension for old age have lost their explanatory power, but have remained equally important as predictors for pension amounts.

Table 4.1.5. Dynamic models of pension coverage and income in China

\begin{tabular}{|c|c|c|c|}
\hline \multirow[b]{2}{*}{ Age group: $65+$} & \multicolumn{2}{|c|}{ Pension coverage, 2015} & \multirow{2}{*}{$\begin{array}{c}\text { Pension Income, } 2015 \\
(3)\end{array}$} \\
\hline & (1) & $(2)$ & \\
\hline Regressor & \multicolumn{2}{|c|}{$\begin{array}{c}\text { Average marginal effects from logit } \\
\text { regression }\end{array}$} & $\begin{array}{l}\text { Coefficients from linear } \\
\text { regression }\end{array}$ \\
\hline \multirow[t]{2}{*}{ Age } & $0.010^{* \star *}$ & $0.022^{\star \star \star}$ & -141.157 \\
\hline & $(0.002)$ & $(0.003)$ & $(483.188)$ \\
\hline \multirow[t]{2}{*}{ Female } & $0.040^{* *}$ & $0.036^{\star \star}$ & -484.136 \\
\hline & $(0.020)$ & $(0.016)$ & $(451.699)$ \\
\hline \multirow[t]{2}{*}{ Married } & 0.018 & $0.159^{*}$ & $1,173.951^{* *}$ \\
\hline & $(0.085)$ & $(0.090)$ & $(555.698)$ \\
\hline \multirow[t]{2}{*}{ Partnered/separated/divorced/widowed } & 0.034 & $0.162^{*}$ & 274.637 \\
\hline & $(0.087)$ & $(0.092)$ & $(646.471)$ \\
\hline \multirow[t]{2}{*}{ Upper secondary \& vocational training } & -0.067 & -0.013 & $7,438.805$ \\
\hline & $(0.057)$ & $(0.035)$ & $(5,987.070)$ \\
\hline \multirow[t]{2}{*}{ Tertiary educ. } & & & $31,979.637^{* * *}$ \\
\hline & & & $(4,814.837)$ \\
\hline \multirow[t]{2}{*}{ Rural hukou, 2011} & & & -904.026 \\
\hline & & & $(1,128.075)$ \\
\hline \multirow[t]{2}{*}{ Rural hukou, 2013} & & & $-5,474.471^{\star * *}$ \\
\hline & & & $(1,288.905)$ \\
\hline \multirow[t]{2}{*}{ Rural hukou, 2015} & $0.110^{* *}$ & $0.142^{\star *}$ & $-3,921.001^{* *}$ \\
\hline & $(0.051)$ & $(0.065)$ & $(1,549.854)$ \\
\hline \multirow[t]{2}{*}{ Enrolled in pub. pension progr. } & -0.049 & $-0.122^{* *}$ & $-1,086.770$ \\
\hline & $(0.062)$ & $(0.061)$ & $(909.990)$ \\
\hline \multirow[t]{2}{*}{ Working, 2011} & $0.076^{* * *}$ & $0.079^{* * *}$ & $-1,285.715^{\star \star *}$ \\
\hline & $(0.025)$ & $(0.030)$ & $(492.647)$ \\
\hline \multirow[t]{2}{*}{ Working, 2013} & 0.017 & -0.010 & -849.054 \\
\hline & $(0.040)$ & $(0.032)$ & $(736.866)$ \\
\hline \multirow[t]{2}{*}{ Earnings 2011 (log) } & 0.002 & $-0.007^{* * *}$ & -91.046 \\
\hline & $(0.005)$ & $(0.003)$ & $(154.764)$ \\
\hline \multirow[t]{2}{*}{ Earnings 2013 (log) } & -0.001 & -0.001 & 18.455 \\
\hline & $(0.003)$ & $(0.003)$ & $(69.035)$ \\
\hline Ever worked for pay & $0.245^{\star \star}$ & & \\
\hline
\end{tabular}


Self-employed, 2001

Self-employed, 2003

Interaction female $\mathrm{x}$ marital status Interaction female $x$ education Interaction rural $x$ education Lags of hours worked Lags of part time work Constant

\section{Observations}

(0.114)

$\begin{array}{lll} & 0.058 & -116.818 \\ & (0.039) & (580.507) \\ & -0.024 & -1,573.949^{*} \\ & (0.045) & (816.429) \\ Y & Y & Y \\ Y & Y & Y \\ N & N & Y \\ Y & Y & Y \\ N & Y & Y \\ & & 17,918.131 \\ 3,781 & 4,152 & (18,116.944) \\ & & 2,042\end{array}$

Robust standard errors in parentheses. ${ }^{* *} p<0.01,{ }^{* *} p<0.05,{ }^{*} p<0.1$ Notes: All models include a second order polynomial on age.

\subsection{Mexico}

As described in the Background section, the expansion of social protection in Mexico has been almost exclusively done through noncontributory programs, including the noncontributory pension program Programa Pensión para Adultos Mayores (PPAM). Given that it does not have a contributory component, it is often the case that datasets do not count their recipients among the public pension benefit recipients. This is the case in the analyzed MHAS survey waves.

If one uses exclusively the public pension definition used in MHAS, we see a low level of coverage and almost null growth in the 2002 to 2012 period. The proportion of individuals 70 and older covered in 2012 was 24.7 percent, and grew only by 0.1 percentage points over a decade (Panel A of Figure 4.2.1). Both the level and growth contrast sharply with the results for China analyzed above. However, once we add the recipients of the noncontributory programs, the pattern is different. We use a variable that we created by indicating a person as a public pension beneficiary if he or she receives either a traditional contributory public pension (including IMSS or ISSSTE) or a transfer from a public program for elders (including the PPAM). This provides a more accurate comparison to the cases of China, and a more complete panorama of the evolution of social security coverage in Mexico. In this case, coverage grows 
from 32.7 percent to 55.6 percent among those 70 and older (Panel B of Figure 4.2.1). There is almost no growth among those 60 to 65 and 65 to 69 , which is explained by the fact that the PPAM only covered those 70 and older before 2013 (see Background section).

Figure 4.2.1: Recipients of public pensions in Mexico by age group

Panel A. Pension receipt (from traditional contributory public pensions)

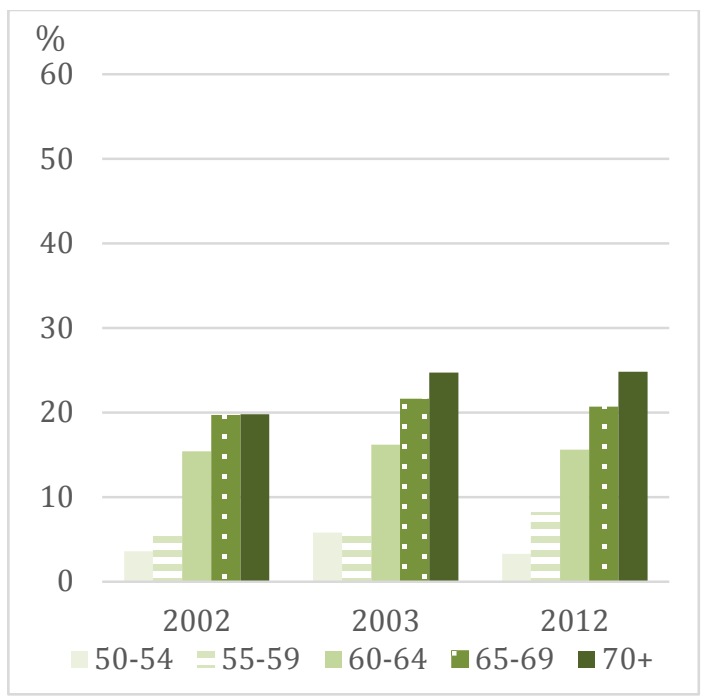

Panel B. Pension receipt (including PPAM and other public programs) *

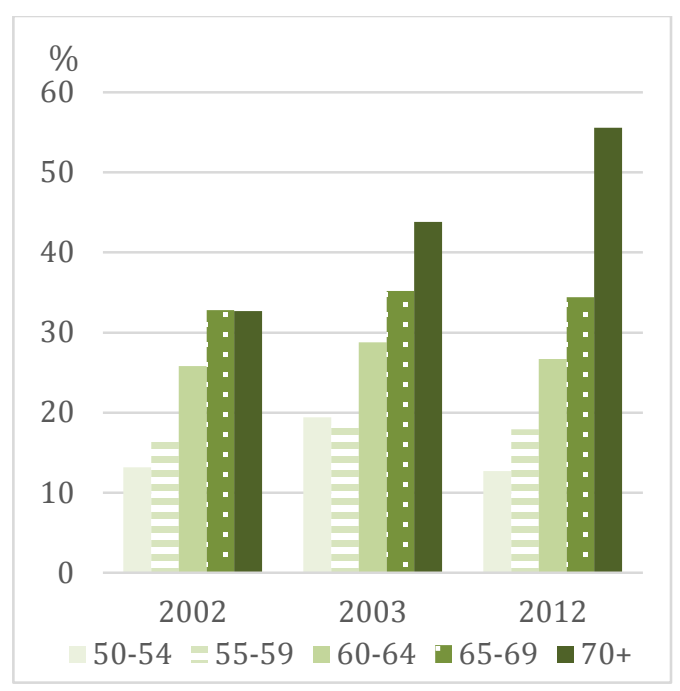

Note: Shares of each age group covered by public pensions. *This variable indicates if respondent has a contributory pension or receives benefit from other government transfers which includes the PPAM.

Table 4.2.1 shows the evolution of pension coverage among those 65 and older in Mexico, by subgroups. The fraction covered according to the definition with contributory programs only (the "exclusive definition") grew from 22 percent to 28 percent overall. The growth was higher among men: 26 percent to 30 percent, versus 14 percent to 17 percent among women. On the other hand, the variable including non-contributory programs (the "inclusive definition"), shows a steeper growth, from 33 percent to 48 percent, which was higher among women ( 25 percent to 43 percent, versus 41 percent to 53 percent among men). 
Coverage grew only among those with lower and middle levels of education. Among those with less than lower secondary education, coverage grew from 31 percent to 48 percent according to the inclusive definition, while it showed a slight decline among those with tertiary education (56 percent to 50 percent). This resulted in the elimination of an education gradient in coverage (when using the inclusive definition). In 2001, those with tertiary education were 25 percentage points more likely to be covered than those with less than lower secondary (56 percent versus 31 percent). By 2012, however, both groups were about as likely to be covered (50 percent versus 48 percent).

Growth was also concentrated exclusively among those 70 or older: from 20 percent to 25 percent with the exclusive definition, and from 33 percent to 56 percent with the inclusive definition. This compares to a 1 percentage point growth among the 60 to 69 with either definition of coverage.

Table 4.2.1: Recipients of public pension in Mexico, percentages (65 and older)

\begin{tabular}{|c|c|c|c|c|c|c|}
\hline \multirow[b]{2}{*}{$\begin{array}{r}\text { Fraction who receives } \\
\text { public pension, ages } 65+\end{array}$} & \multicolumn{3}{|c|}{ Contributory programs only } & \multicolumn{3}{|c|}{$\begin{array}{l}\text { Including noncontributory programs } \\
\text { (such as PPAM) }\end{array}$} \\
\hline & 2001 & $2002-2003$ & 2012 & 2001 & $2002-2003$ & 2012 \\
\hline & 21.7 & 24.5 & 27.6 & 32.7 & 40.7 & 47.9 \\
\hline Male & 25.7 & 30.6 & 30.1 & 40.6 & 47.4 & 53.2 \\
\hline Female & 14.1 & 16.9 & 17.1 & 25.1 & 34.4 & 43.3 \\
\hline $\begin{array}{l}\text { Less than lower } \\
\text { secondary education }\end{array}$ & 17.9 & 21.3 & 21.7 & 31.4 & 39.2 & 47.9 \\
\hline $\begin{array}{l}\text { Upper secondary \& } \\
\text { vocational training }\end{array}$ & 55.3 & 46.2 & 42.7 & 56.9 & 54.6 & 53.5 \\
\hline Tertiary education & 54.4 & 66 & 49.2 & 55.9 & 69 & 50.2 \\
\hline Age $60-69$ & 19.7 & 21.6 & 20.7 & 32.8 & 35.2 & 34.4 \\
\hline Age $70+$ & 19.8 & 24.7 & 24.8 & 32.7 & 43.8 & 55.6 \\
\hline Never married & 16 & 20.3 & 15.6 & 36.1 & 37.4 & 37.6 \\
\hline Married & 19.6 & 25.1 & 21.5 & 32.1 & 39.6 & 45.6 \\
\hline $\begin{array}{l}\text { Partnered/separated/ } \\
\text { divorced/widowed }\end{array}$ & 20.4 & 22.1 & 26.5 & 33.1 & 42.3 & 52.2 \\
\hline Working & & 11.7 & 11.6 & & 31.4 & 40.7 \\
\hline Retired & & 87.5 & 84.7 & & 89.1 & 86 \\
\hline Retired and other status & & & 76.3 & & & 80.7 \\
\hline
\end{tabular}




$\begin{array}{rcc}\text { Population }=100,000+ & 37.4 & 47.46 \\ \text { Population }=15,000- & 23.2 & 40.77 \\ 99,999 & & \\ \text { Population }=2,500- & 13.3 & 43.92 \\ 14,999 & & \\ \text { Population }<2,500 & 7.7 & 53.92\end{array}$

As in the case of China, the education gradient remains when analyzing average pension amounts, which are shown for the last MHAS wave in Table 4.2.2. While the average pension amount was about MXN 46 thousand for those in the lowest education group, it was more than double that amount among the highest group. Average pension income was about the same across genders and was slightly higher among the 70 and older than among the 65 to 69 age group.

Table 4.2.2. Mean public pension income by demographic characteristic, Mexico

\begin{tabular}{lc}
\hline Total pension income if retired, 2011 & $\begin{array}{c}\text { Average } \\
\text { (in 2010 MXN) }\end{array}$ \\
\hline All & $55,464.80$ \\
Male & $54,306.80$ \\
Female & $59,593.50$ \\
Less than lower secondary educ. & $45,896.50$ \\
Upper secondary \& vocational training & $96,499.10$ \\
Tertiary educ. & $98,111.20$ \\
Age 65-69 & $52,398.50$ \\
Age 70+ & $57,114.40$ \\
Never married & $69,516.50$ \\
Married & $61,060.10$ \\
Partnered/separated/divorced/widowed & $45,680.00$ \\
\hline
\end{tabular}


Table 4.2.3 shows the significant growth in the fraction of beneficiaries of public programs (which, in this case, includes the PPAM as well as other cash-transfer programs). While there has been modest growth among the middle aged, with the percentages receiving benefit growing from 10.3 to 12.3 among the 45 to 49 and slightly declining among the 50 to 59 , the growth among those 70 and older is the driving force. The proportion more than doubles between 2001 and 2012, clearly reflecting the introduction and expansion of the PPAM.

Furthermore, this increase has been concentrated among those with lower secondary education, reflecting the targeting of the program, which originally was only in rural areas and small towns, with predominantly poorer populations.

\section{Table 4.2.3 Respondents receiving income form public programs in Mexico, percentages (Ages 45 years and older)}

\begin{tabular}{r|lll} 
Year & $\mathbf{2 0 0 1}$ & $\mathbf{2 0 0 3}$ & $\mathbf{2 0 1 2}$ \\
\hline Less than lower secondary & 12.9 & 16.7 & 18.8 \\
$\begin{array}{r}\text { education } \\
\text { Upper secondary \& vocational } \\
\text { training }\end{array}$ & 1.4 & 5.2 & 3.7 \\
Tertiary education & 2.3 & 3.5 & 2.5 \\
Age 45-49 & 10.3 & 14.5 & 12.3 \\
Age 50-59 & 10.4 & 13.3 & 9.7 \\
Age 60-69 & 12.5 & 13.7 & 12.8 \\
Age 70+ & 14.4 & 20.8 & 34.6
\end{tabular}

Table 4.2.4 shows the fraction of adults 45 or older who receive disability insurance. The variable was not asked in the third wave of the MHAS, so we only report it for the first two waves. The fraction is largely unchanged across the two years, but the numbers are too small to do analysis of differences across groups. 
Table 4.2.4: Recipients of disability insurance in Mexico, percentages (45 and older)

\begin{tabular}{r|cc} 
Year & $\mathbf{2 0 0 1}$ & $\mathbf{2 0 0 2 - 2 0 0 3}$ \\
Male & 2 & 0.94 \\
Female & 1.2 & 1.3 \\
& & 0.6 \\
Less than lower secondary & 1.4 & 0.9 \\
education & & \\
Upper secondary \& vocational & 0.6 & 0.8 \\
training & & \\
Tertiary education & 3.4 & 1.4 \\
Age 45-49 & 0 & 0.3 \\
Age 50-59 & 1.8 & 0.8 \\
Age 60-69 & 1.6 & 1.1 \\
Age 70+ & 1.1 & 0.9 \\
& & \\
Never married & 1.6 & 0.7 \\
Married & 1.7 & 0.8 \\
wed & 1.2 & 1.2 \\
Partnered/separated/divorced/wido & & \\
Working & & \\
Retired & & 0.5 \\
\end{tabular}

Mexico did not provide unemployment benefits during the years covered in this data (ILO 2018). However, there are severance payment rules, though enforcement of them is low (Kaplan and Sadka 2008).

Another important aspect of the expansion of social security coverage is the introduction of the Seguro Popular which consisted of health insurance for those not covered by IMSS and ISSSTE, the traditional social security programs. The Seguro Popular was introduced in 2002, and it was gradually rolled-out after that (Aterido et al. 2011). Figure 4.2.2 shows the increase in health insurance coverage resulting from this program. Before the introduction of Seguro 
Popular, being covered by public health insurance (through IMSS and ISSSTE) was a good indicator of employment in the formal sector.

\section{Figure 4.2.2: Enrollment in public health insurance in Mexico}

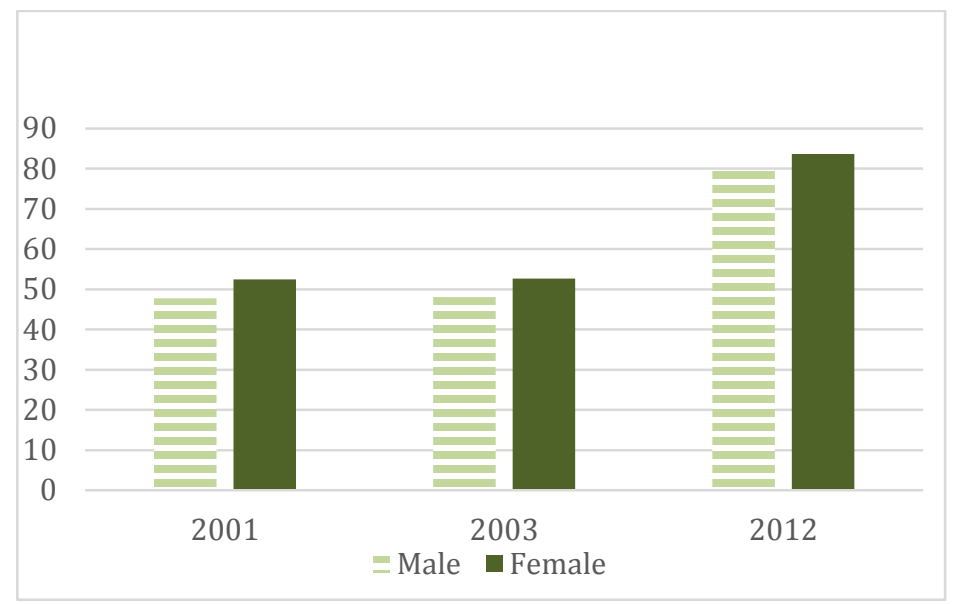

Note: Fraction covered by government health insurance, 45 and older

\section{Regression models}

An alternative way to show how the characteristics of the covered population are changing is to analyze its correlates from a regression model. Table 4.2 .5 below shows regressions using data from each of the waves. In the first wave for Mexico, having a public pension (with either definition) was positively predicted by higher education status, and negatively affected by being female.

The positive coefficients for the middle and high education categories remain positive and highly significant in the second and third waves when the dependent variable is pension receipt according to the exclusive definitions (shown in Columns 1 to 3). However, these coefficients are importantly reduced when using the inclusive definition (Columns 4 to 6). For instance, the effect of tertiary education was to increase the probability of pension receipt by 0.24 in the model of Column 4, but only by 0.11 in the model of Column 6 . 
Table 4.2.5. Cross-Sectional Regression Models of Social Security Benefit Receipt and Eligibility in Mexico

\begin{tabular}{|c|c|c|c|c|c|c|}
\hline \multirow{4}{*}{ Age group } & \multicolumn{3}{|c|}{$\begin{array}{c}\text { Pension Coverage } \\
\text { Contributory programs only }\end{array}$} & \multicolumn{3}{|c|}{$\begin{array}{c}\text { Pension Coverage } \\
\text { Including noncontributory programs }\end{array}$} \\
\hline & 2001 & $2002-03$ & 2011 & 2001 & $2002-03$ & 2011 \\
\hline & $65+$ & $65+$ & $65+$ & $65+$ & $65+$ & $65+$ \\
\hline & (1) & $(2)$ & (3) & (4) & $(5)$ & (6) \\
\hline Regressor & \multicolumn{6}{|c|}{ Average marginal effects from logit regression } \\
\hline Age & $\begin{array}{l}0.003^{*} \\
(0.002)\end{array}$ & $\begin{array}{c}0.002 \\
(0.002)\end{array}$ & $\begin{array}{l}0.003^{* *} \\
(0.001)\end{array}$ & $\begin{array}{l}0.003^{*} \\
(0.002)\end{array}$ & $\begin{array}{l}0.006^{* *} \\
(0.002)\end{array}$ & $\begin{array}{l}0.019 * * * \\
(0.002)\end{array}$ \\
\hline Female & $\begin{array}{l}-0.092^{* * *} \\
(0.022)\end{array}$ & $\begin{array}{l}-0.093^{* * *} \\
(0.026)\end{array}$ & $\begin{array}{l}-0.130 * * * \\
(0.022)\end{array}$ & $\begin{array}{l}-0.125^{\star * *} \\
(0.028)\end{array}$ & $\begin{array}{l}-0.106^{* * *} \\
(0.031)\end{array}$ & $\begin{array}{l}-0.123^{\star * *} \\
(0.026)\end{array}$ \\
\hline Married & $\begin{array}{l}0.025 \\
(0.038)\end{array}$ & $\begin{array}{c}0.052 \\
(0.041)\end{array}$ & $\begin{array}{c}0.035 \\
(0.031)\end{array}$ & $\begin{array}{l}-0.000 \\
(0.059)\end{array}$ & $\begin{array}{c}0.016 \\
(0.066)\end{array}$ & $\begin{array}{l}0.013 \\
(0.055)\end{array}$ \\
\hline $\begin{array}{l}\text { Not married, not } \\
\text { single }\end{array}$ & $\begin{array}{l}0.082^{* *} \\
(0.039)\end{array}$ & $\begin{array}{l}0.068^{*} \\
(0.041)\end{array}$ & $\begin{array}{l}0.134^{* * *} \\
(0.035)\end{array}$ & $\begin{array}{l}0.071 \\
(0.060)\end{array}$ & $\begin{array}{r}0.078 \\
(0.067)\end{array}$ & $\begin{array}{l}0.062 \\
(0.058)\end{array}$ \\
\hline $\begin{array}{l}\text { Upper secondary \& } \\
\text { vocational training }\end{array}$ & $\begin{array}{l}0.183^{* *} \\
(0.076)\end{array}$ & $\begin{array}{l}0.144^{*} \\
(0.084)\end{array}$ & $\begin{array}{l}0.238^{* * *} \\
(0.069)\end{array}$ & $\begin{array}{l}0.045 \\
(0.077)\end{array}$ & $\begin{array}{r}0.070 \\
(0.088)\end{array}$ & $\begin{array}{l}0.075 \\
(0.075)\end{array}$ \\
\hline Tertiary educ. & $\begin{array}{l}0.373^{* * *} \\
(0.086)\end{array}$ & $\begin{array}{l}0.434^{* * *} \\
(0.075)\end{array}$ & $\begin{array}{l}0.324^{* * *} \\
(0.051)\end{array}$ & $\begin{array}{l}0.241^{* * *} \\
(0.085)\end{array}$ & $\begin{array}{l}0.298^{* * *} \\
(0.067)\end{array}$ & $\begin{array}{l}0.106^{* *} \\
(0.047)\end{array}$ \\
\hline Ever worked for pay & $\begin{array}{l}0.080^{* * *} \\
(0.031)\end{array}$ & $\begin{array}{l}0.117^{\star * *} \\
(0.036)\end{array}$ & $\begin{array}{c}0.043 \\
(0.026)\end{array}$ & $\begin{array}{l}0.103^{* * *} \\
(0.033)\end{array}$ & $\begin{array}{l}0.082^{* *} \\
(0.036)\end{array}$ & $\begin{array}{l}-0.015 \\
(0.029)\end{array}$ \\
\hline $\begin{array}{l}\text { Interaction female } x \\
\text { marital status }\end{array}$ & Y & Y & Y & Y & Y & Y \\
\hline $\begin{array}{l}\text { Interaction female } x \\
\text { education }\end{array}$ & Y & Y & Y & Y & Y & Y \\
\hline Observations & 5,038 & 4,939 & 6,971 & 5,048 & 4,986 & 6,972 \\
\hline
\end{tabular}

Robust standard errors in parentheses. ${ }^{* * *} p<0.01,{ }^{* *} p<0.05,{ }^{*} p<0.1$ Note: All regression models include a second order polynomial on age. 
Table 4.2.6 shows similar regression models, but where the dependent variable is the annual income amount (deflated to be made comparable across rounds). Contrary to what occurs with the coverage outcomes, here the coefficients are very stable. In all cases, education is strongly and positively correlated with the pension amount, and the coefficients are similar in magnitude across waves.

Column 3 presents results of a logit model where the dependent variable is a proxy for whether the individual is eligible for Social Security, which takes a value of 1 if the respondent is covered by public health insurance. The sample is composed of adults 45 and older. In this case, there are few predictors that are quantitatively important, as health insurance coverage is no longer associated with employment in the formal sector since the introduction of Seguro Popular. Column 4 presents results for other government transfers (including non-contributory pension programs). The coefficients for the middle and higher education categories are strongly negative and significant, since the non-contributory social programs are targeted to those with lower income (who tend to have lower levels of education). 
Table 4.2.6. Cross-Sectional Regression Models of Social Security Benefit Income and Eligibility in Mexico

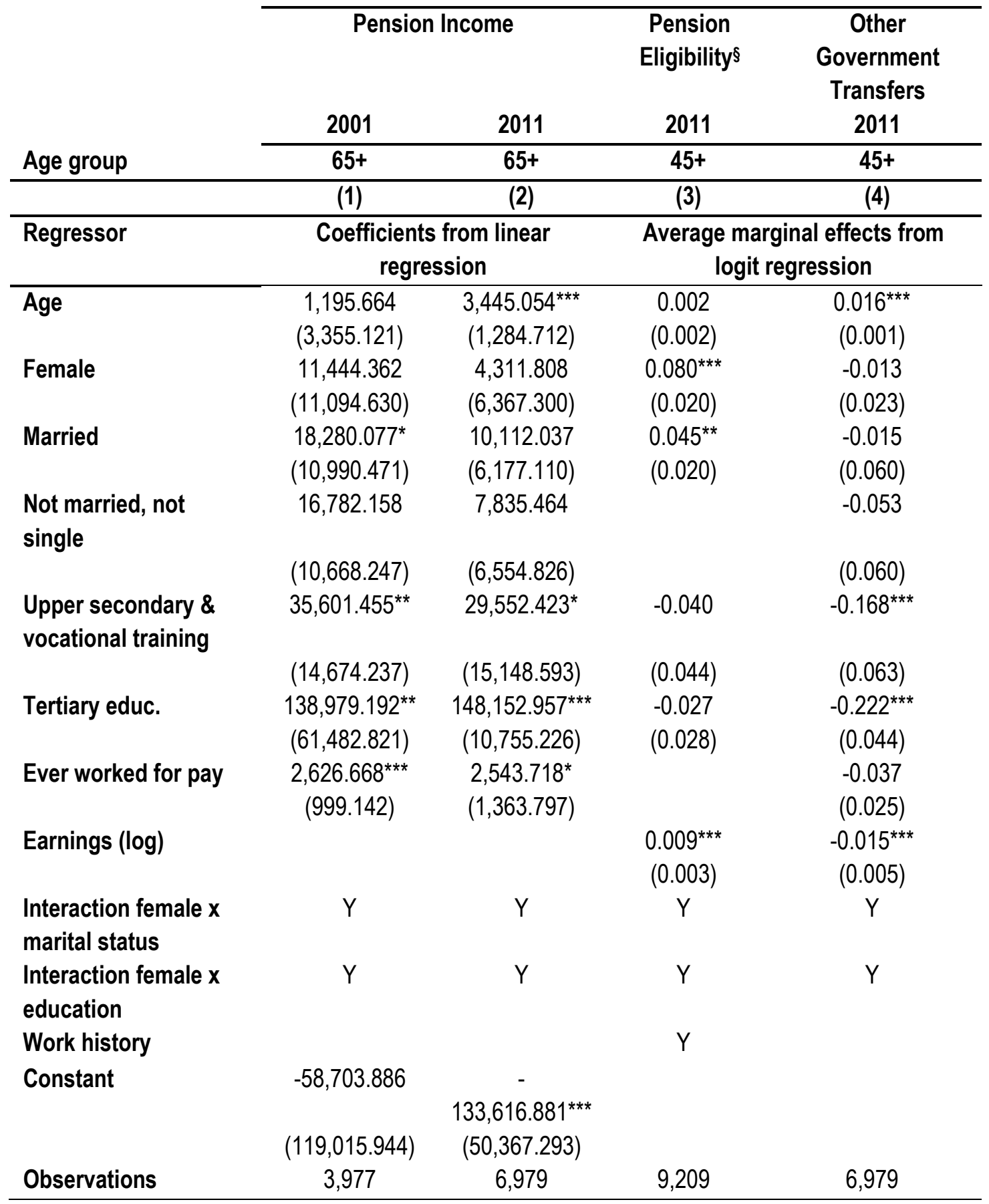

Robust standard errors in parentheses. ${ }^{* * *} p<0.01,{ }^{* *} p<0.05,{ }^{*} p<0.1$. Note:

All regression models include a second order polynomial on age. ${ }^{\S}$ Pension eligibility is defined as being covered by public health insurance

As for the case of China, we exploit the panel data aspect to analyze individuals' transitions across the survey waves. As described in the methodology subsection (3.2), we 
regress the outcome variable of interest in the most recent wave against a set of labor market and demographic variables measured both contemporaneously and in the earlier waves. In particular, this allows us to estimate the effect of labor force status in 2002 and 2004 on individuals who are older than 65 in 2012. The dependent variables of interest are, in turn, the indicator of whether the respondent receives a public pension, and the total amount received.

Table 4.2.7 below shows these results. Results for pension coverage are shown in Columns 1 to 3 - only for the exclusive definition. Several variables are strongly significant and of the expected sign. Being a woman has a negative and strongly significant coefficient, while education has strongly significant positive coefficients (as is having worked in wave 1). However, most of the labor force status variables do not have much explanatory power, mostly because the variable government health insurance, 2001 and 2003 absorbs most of that effect. ${ }^{8}$

The results shown in the last column of the table correspond to a linear regression of the income amount against the set of variables from the concurrent and prior waves. The labor market variables are of the expected signs, with having worked part-time or as self-employed negatively predicting pension income. The education dummies are positive, and having tertiary education is associated with MXN 75,000 per year in pension income.

\footnotetext{
${ }^{8}$ This variable is often used as an indicator of whether the individual works in the formal sector (Kaplan and Perez Arce Novaro 2006). It works as a proxy for formal sector employment before the expansion of Seguro Popular, which offered public health insurance to individuals in the informal sector)
} 
Table 4.2.7. Dynamic models of pension coverage and income in Mexico

\begin{tabular}{|c|c|c|c|c|}
\hline \multirow[b]{2}{*}{ Age group: $65+$} & \multicolumn{3}{|c|}{ Pension coverage, 2011} & \multirow{2}{*}{$\begin{array}{c}\begin{array}{c}\text { Pension } \\
\text { Income }\end{array} \\
2011 \\
\end{array}$} \\
\hline & (1) & $(2)$ & (3) & \\
\hline Regressor & \multicolumn{3}{|c|}{$\begin{array}{l}\text { Average marginal effects from } \\
\text { logit regression }\end{array}$} & $\begin{array}{l}\text { Coefficients } \\
\text { from linear } \\
\text { regression }\end{array}$ \\
\hline \multirow[t]{2}{*}{ Age } & -0.001 & 0.001 & 0.001 & $-6,293$ \\
\hline & $(0.002)$ & $(0.001)$ & $(0.001)$ & $(6,264)$ \\
\hline \multirow[t]{2}{*}{ Female } & $-0.203^{\star * *}$ & $-0.193^{\star * *}$ & $-0.200^{* * *}$ & $-4,765$ \\
\hline & $(0.021)$ & $(0.019)$ & $(0.019)$ & $(6,050)$ \\
\hline \multirow[t]{2}{*}{ Married } & $-0.126^{* \star *}$ & $-0.116^{* * *}$ & $-0.118^{* * *}$ & 4,754 \\
\hline & $(0.035)$ & $(0.033)$ & $(0.032)$ & $(8,346)$ \\
\hline \multirow[t]{2}{*}{ Partnered/separated/divorced/widowed } & -0.007 & -0.000 & -0.001 & $-4,304$ \\
\hline & $(0.037)$ & $(0.034)$ & $(0.033)$ & $(7,141)$ \\
\hline \multirow[t]{2}{*}{ Upper secondary \& vocational training } & 0.035 & 0.038 & 0.028 & 47,469 \\
\hline & $(0.076)$ & $(0.051)$ & $(0.051)$ & $(28,951)$ \\
\hline \multirow[t]{2}{*}{ Tertiary educ. } & $0.132^{* * *}$ & $0.087^{* *}$ & $0.092^{* * *}$ & $75,049^{* * *}$ \\
\hline & $(0.037)$ & $(0.034)$ & $(0.034)$ & $(10,148)$ \\
\hline \multirow[t]{2}{*}{ Government health ins, 2001} & $0.190^{* * *}$ & $0.175^{* * *}$ & $0.175^{* * *}$ & $-8,653$ \\
\hline & $(0.024)$ & $(0.024)$ & $(0.024)$ & $(6,116)$ \\
\hline \multirow[t]{2}{*}{ Government health ins, 2003} & $0.243^{* * *}$ & $0.242^{* * *}$ & $0.237^{* * *}$ & $14,837^{* *}$ \\
\hline & $(0.025)$ & $(0.025)$ & $(0.025)$ & $(6,855)$ \\
\hline \multirow[t]{2}{*}{ Working, wave 1} & -0.049 & 0.025 & 0.057 & $-17,647^{* * *}$ \\
\hline & $(0.032)$ & $(0.033)$ & $(0.038)$ & $(5,853)$ \\
\hline \multirow[t]{2}{*}{ Working, wave 2} & $-0.090^{*}$ & $-0.139^{* *}$ & -0.087 & $13,608^{*}$ \\
\hline & $(0.054)$ & $(0.056)$ & $(0.059)$ & $(8,047)$ \\
\hline \multirow[t]{2}{*}{ Earnings 2001 (log) } & $0.010^{* * *}$ & $0.007^{* * *}$ & $0.007^{* *}$ & 617 \\
\hline & $(0.003)$ & $(0.003)$ & $(0.003)$ & $(389)$ \\
\hline \multirow[t]{2}{*}{ Earnings 2003 (log) } & 0.002 & 0.001 & 0.001 & -227 \\
\hline & $(0.003)$ & $(0.003)$ & $(0.003)$ & $(427)$ \\
\hline \multirow[t]{2}{*}{ Ever worked for pay } & 0.022 & & & \\
\hline & $(0.023)$ & & & \\
\hline \multirow[t]{2}{*}{ Self-employed, 2001} & & $-0.118^{* * *}$ & $-0.099^{* * *}$ & $-6,391$ \\
\hline & & $(0.029)$ & $(0.029)$ & $(5,160)$ \\
\hline \multirow[t]{2}{*}{ Self-employed, 2003} & & $0.079^{*}$ & 0.042 & 2,051 \\
\hline & & $(0.047)$ & $(0.046)$ & $(9,927)$ \\
\hline \multirow[t]{2}{*}{ Tenure in years, 2001} & & & $-0.001^{*}$ & \\
\hline & & & $(0.001)$ & \\
\hline \multirow[t]{2}{*}{ Tenure in years, 2003} & & & $-0.002^{\star *}$ & \\
\hline & & & $(0.001)$ & \\
\hline Interaction female $\mathrm{x}$ marital status & Y & Y & Y & Y \\
\hline Interaction female $\mathrm{x}$ education & Y & Y & Y & Y \\
\hline Lags of hours worked & Y & Y & Y & Y \\
\hline Lags of part time work & $\mathrm{N}$ & Y & Y & Y \\
\hline
\end{tabular}




\begin{tabular}{lcccc}
$\begin{array}{l}\text { Lags of private health insurance } \\
\text { Constant }\end{array}$ & $Y$ & $Y$ & $Y$ & $Y$ \\
& & & & 315,353 \\
Observations & 5,407 & 5,857 & 5,857 & 1,650 \\
\hline
\end{tabular}

Robust standard errors in parentheses. ${ }^{* *} p<0.01,{ }^{* *} p<0.05,{ }^{*} p<0.1$ Notes:

All models include a second order polynomial on age. Past coverage of

private health insurance is not statistically significant in any specification.

Overall, and similar to the case of China, the results presented in this section are consistent with a "decoupling" of the labor history with pension coverage, though not when using the "exclusive" definition. Also, similarly to China, this decoupling does not translate to other outcomes, such as average pension income.

\section{Projections and scenario simulations}

From the results in Section 4, we learned that the introduction or expansion of programs with non-contributory components have weakened the association between education, urban status, and formal sector employment with public pension receipt, but the association with pension income amount has remained very strong.

To better understand the magnitude of these relationships, we conduct projections and scenario simulations that use as a base the regression models with coverage and pension income as dependent variables, and demographic and employment variables as regressors estimated in Section 4 . The result is a predictive model that allows us to calculate counterfactuals that give us insights into how further changes in the labor markets may affect social security.

The main purpose of these exercises is to evaluate "what if" scenarios related to projected or possible changes in the labor market, for example, "what if the informal sector diminishes in importance," or "what if education levels were higher." For each of these scenarios, we assess likely changes in social security coverage and average pension income. 
Conceptually, there are two ways of constructing the counterfactual scenarios. To fix ideas, consider the example of an exercise where we want to analyze what our model would predict if tertiary education rates were higher. A first approach is to construct alternative demographic compositions to the actual population. In this case, we artificially endow a cohort with increased tertiary education rates. We compute the "counterfactual population" by altering the relative weights of the individuals in the sample, that is, by increasing the probabilistic weights of the subpopulation with the desired characteristic (in this example, those with tertiary education). This approach changes the population distribution of any other characteristic correlated with the main variable of interest. For instance, if those with secondary education are more likely to be working, then increasing the weights of the high school graduates changes the demographic composition by work status as well. A second approach is to instead change the values of the regressors directly (instead of changing the probabilistic weights). For instance, and to continue with our example, we randomly select observations with less education and change its value (i.e. "give them" secondary education). This approach keeps constant the distribution of the rest of the characteristics in the sample.

In practice with our data, we found the results to be qualitative similar. Therefore, we present here only our results using the second approach (Appendix A.2 includes the figures with results from the counterfactuals using the first approach).

Our strategy comprises the following steps:

1. Compute the outcomes of interest for the 65 and older population (as of the last survey wave). We refer to this as the current situation.

2. Compute the means of the regressors for the respondents 65 and older and predict the outcomes of interest for these means using the estimated regression models. This is the predicted current situation. As expected, these outcomes are very similar to the current situation, although they are not numerically identical because the models are nonlinear. 
3. Replace the means of the regressors for the respondents 65 and older in the previous scenario by the corresponding means for those 45 to 65 , except for age and its square. Thus, this considers a hypothetical population ages $65+$ in 2030 that, aside from age, looks like the current population ages 45 to 64 in terms of educational attainment, work history, and demographics. Then predict the outcomes of interest for these hypothetical means using the regression models. This is the baseline scenario.

4. For the counterfactual scenarios, we take the baseline scenario, modify one or more of its regressors, and then predict the outcomes of interest using the regression models.

These scenarios give approximate indications of how expected and hypothetical changes in population characteristics may affect public pension receipt and total pension income. Much larger effects are expected of recent (and possibly future) policy changes, specifically the recently introduced public pension schemes discussed in earlier sections. As we have argued, changes in policy across China and Mexico have had very large effects. The policy landscape is evolving, and we cannot predict how it will change in the near future. Therefore, our projections should not be thought of as reliable predictions of the levels of social security coverage.

\subsection{China}

\section{Gender ratios}

The gender ratio at birth in China, defined as the number of men born for every 100 women, increased from its natural rate of 107 to an all-time high of 121 in 2004. Since then it has decreased, reaching 113.5 in 2015. This ratio, one of the highest in the world, is forecast to drop below 112 by 2020 and then rise again to 107 by 2030 (State Council 2017). We analyze the potential impact of this sudden increase in gender ratio. For this, we change the gender ratio of the current cohorts starting from the assumption that changes in gender balance at birth and are reflected in proportional changes in gender balances at older ages. This is a first-order 
approximation, as there are gender differences in mortality for which we are not accounting. For these counterfactual scenarios, we simulate the model with higher gender ratios, consistent with the ones for current generations born after the 1980s. The gender ratio at birth of the current cohort was 107 men per 100 women. We adjust the gender ratio of the counterfactual cohort proportionally to increases from the baseline 107 to 112,118 , and the historical maximum, 121 .

Figure 5.2.1 shows that our model predicts that changes in gender composition of the population, even in the most extreme case of an increase to its historical maximum, would not affect pension coverage or average pension income.

\section{Figure 5.2.1: Two Simulations of Social Security pension coverage and pension income under changes in the Gender Ratio, China}

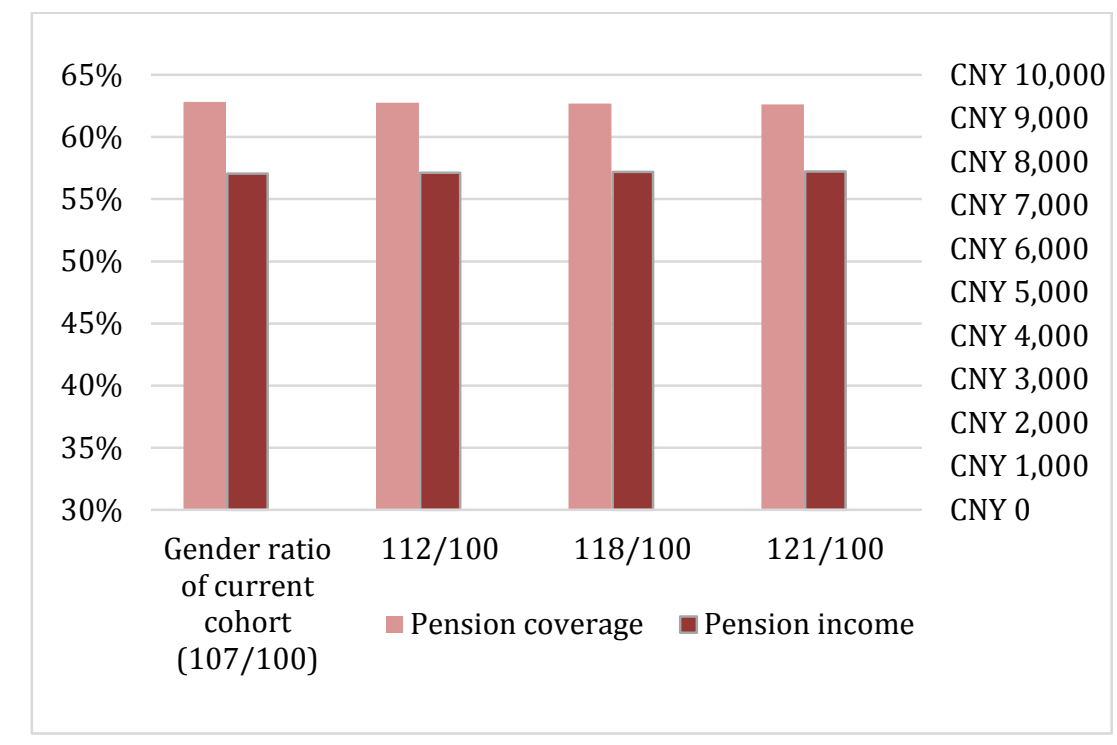

Scenarios of increased gender ratio at birth (men per 100 women). 


\section{Rural population share decline}

The fraction of rural population in China has decreased quickly during the past four decades. In 1977, 82.5 percent of China's population was rural, while that share dropped to 42 percent in $2017 .^{9}$

This scenario presents changes in coverage rates if we assume continued decline in the share of workers living in rural areas. The declining trend in the share of rural population has been linear during the last couple of decades. If we assume the trend continues, we would expect a decrease of 20 percent in the next decade.

Figure 5.2.2 shows the changes in social security pension coverage for a scenario where the share of rural population decreases by 5 percent, 10 percent, 20 percent, and 30 percent. Such reductions would result in decreased coverage rates but increase average pension amounts. The difference among the most extreme change in urbanization rates would amount to a reduction in coverage rates of about 17 percentage points and an increase in average pension amount of more than CNY50,000.

${ }^{9}$ Source: WB https://data.worldbank.org/indicator/SP.RUR.TOTL.ZS?locations $=\mathrm{CN}$ 
Figure 5.2.2: Simulations of Social Security pension coverage and pension income under changes in urbanization levels, China

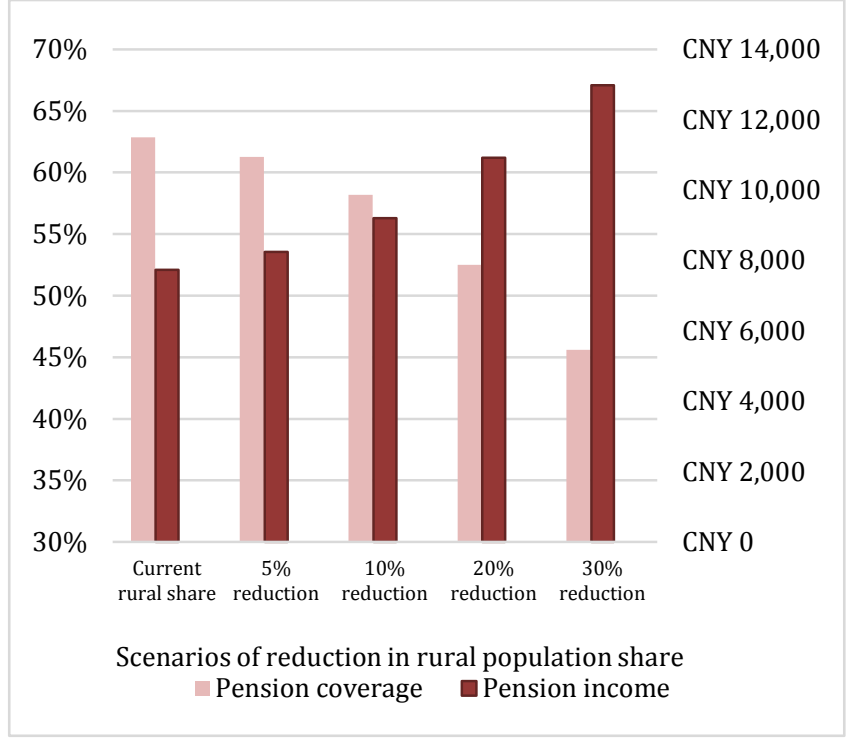

Note: The light-colored bars represent the simulated pension coverage rates, and the dark colored bars show average income under reduced rural population rates

\section{Educational attainment}

Figure 5.2.3 shows the results corresponding to improvements in the educational attainment exercise, where we simulate increases in the proportions completing secondary education of between 10 and 50 percent (to the expense of decreasing low-education and high school drop-out rates). There are strong positive effects on the pension amounts, suggesting that a 10 percent increase in tertiary education rates would increase the pension amount from about CNY7,740 to CNY8,515. A 50 percent increase would further raise it CNY11,657. This is despite the fact that this same simulation would show a reduction in coverage rates, which results from the negative coefficient on education in the regression models estimated with the most recent survey wave. 
Figure 5.2.3: Simulations of Social Security pension coverage and pension income under changes in education levels, China

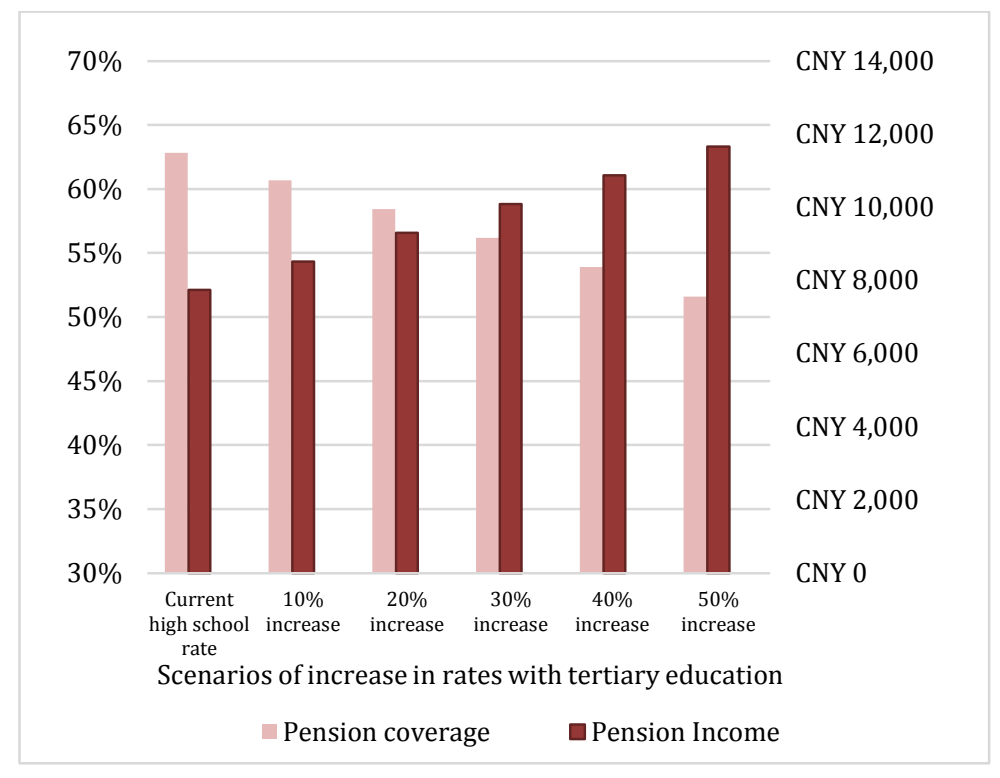

Note: The light-colored bars represent the simulated pension coverage rates, and the dark colored bars show average income under increased tertiary education rates.

\section{Work history}

We also project the impact of changes in economic trends. To account for projected economic growth, we compute scenarios for future social security coverage of the current cohort of working age individuals. We artificially age the currently working-age cohort, and predict their social security pension receipt using the earnings in the current survey data as lagged values in the projections. For this projection, use the results from the dynamic model presented in Table 4.1.5.

In a first exercise, we assume that per capita income keeps growing at the same rate as in the last decade. This implies growth of 20 percent by 2025 , and 40 percent by 2030 . The coverage rate decreases by less than 1 percent under both scenarios ( 0.03 and 0.05 , respectively). Results are not shown for this exercise. 
Furthermore, we simulate what would happen under scenarios where the population share who has "ever worked for pay" increases. This simulation does generate important changes in outcomes, (contrasting with the simulation of changes in per capita income). Results are shown in Figure 5.2.4. A 10 percent increase in this share raises the percentage covered from 63 percent to 65 percent, while a 50 percent increase raises it to 73 percent. It also results in increased pension amounts where the difference in the most extreme simulations reach almost CNY4,000 per year.

\section{Figure 5.2.4: Simulations of Social Security pension coverage and pension income under changes in work history, China}

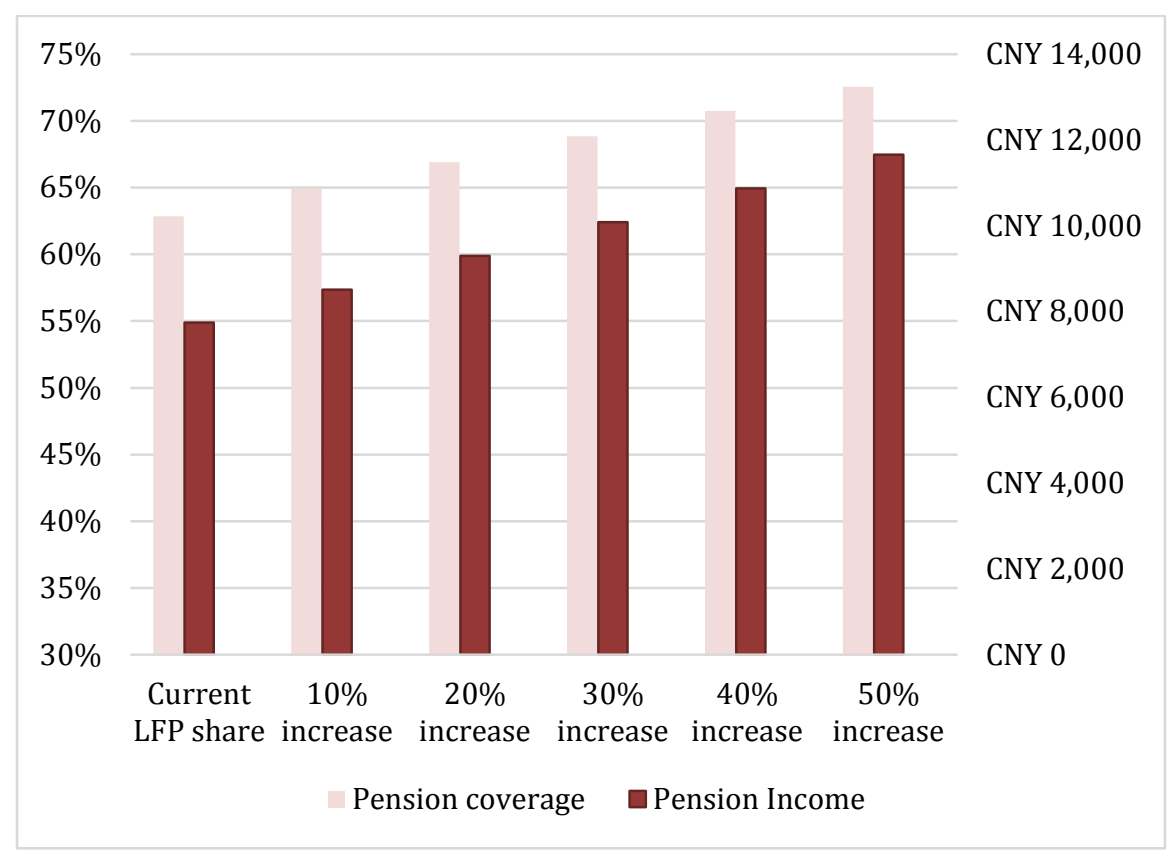

Note: Scenarios of change in population share who has ever worked

\subsection{Mexico}

In the case of Mexico, we present results for the population covered using the "exclusive definition", which counts only those covered by a contributory pension program and for the average yearly pension income. 
Rural population share decline

An important trend in Mexico from the last few decades has been the increase in the share of the population living in cities. The rural population share in Mexico in 1997 was 26 percent, and it fell to 20.2 percent in 2017. We compute scenarios for cases where rural share of Mexico's population further declines.

An increase in urbanization would raise the proportion of the population covered with a contributory pension by up to 3.4 percentage points (under the steepest rural decline). Likewise, the average yearly pension amount would increase by about MX1,000, or about 5 percent of the baseline level.

\section{Figure 5.3.1: Simulations of Social Security pension coverage and pension income under changes in the rural population share, Mexico}

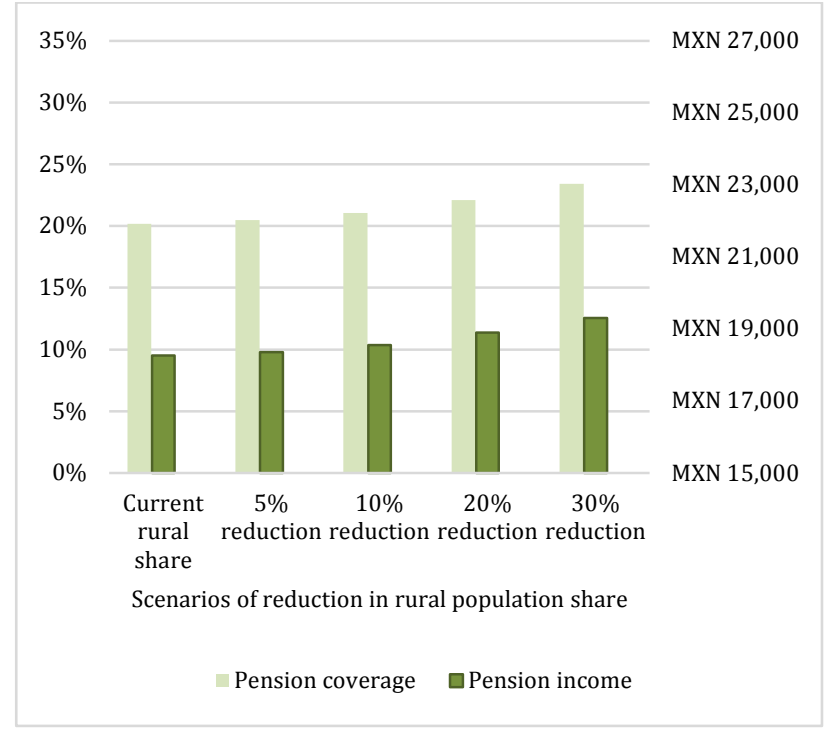

\section{Educational attainment}

The rate of high school graduation is low in Mexico, but has improved over the last couple of decades. The improvement has been similar for both genders: 28.33 percent (32.5) women (men) completed upper secondary education in 2006 and 32.12 percent (34.7 percent) in 2017 
$\left(\right.$ World Bank ${ }^{10}$ ). We analyze counterfactual scenarios that represent further improvements in educational attainment.

Increasing the proportion of individuals with secondary education would result in an increased proportion of the population with a contributory pension program. The increase is not very large, about 6 percentage points (or 30 percent) under the most extreme simulated increase in the tertiary education rate. The increase in the pension amount would be proportionally larger: The average pension amount would increase by more than 40 percent (from MX 18,000 to more than MX 26,000).

Figure 5.3.2: Simulations of Social Security pension coverage and pension income under changes in education levels, Mexico

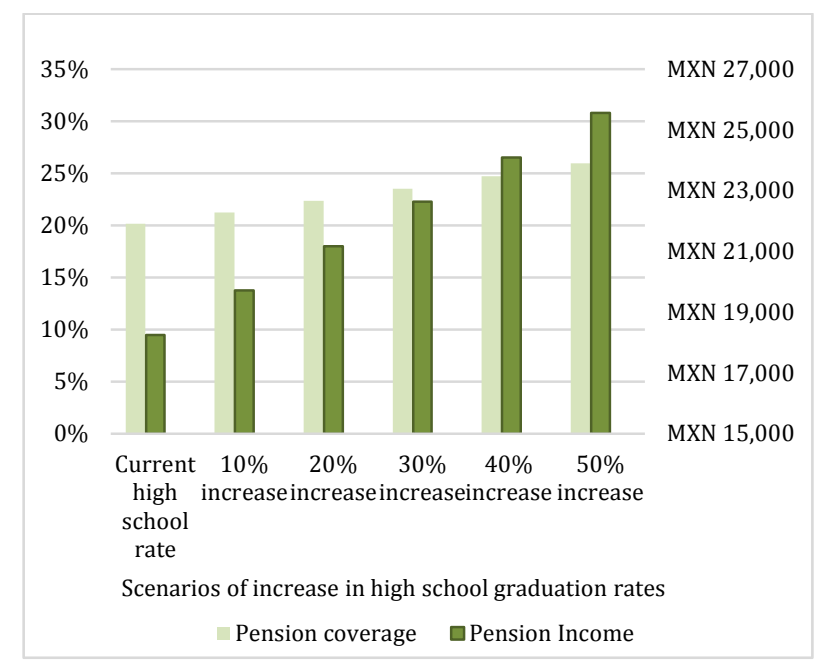

\section{Work history}

There is a large informal sector in Mexico, and our previous results indicate that formality status is a good indicator for pension coverage. We analyze the impact of increases in formality in labor market and in the share of population who has ever worked for pay. The results in Figure 5.3.3 show that if there were increases in the degree of formality, the projected coverage rate

\footnotetext{
${ }^{10}$ World Bank Data https://data.worldbank.org/
} 
would increase. In the case of a 50 percent increase in the share of workers in the formal sector, the coverage rate would go up by 1.8 percent.

\section{Figure 5.3.3: Simulations of Social Security pension coverage and pension income under changes in work history, Mexico}

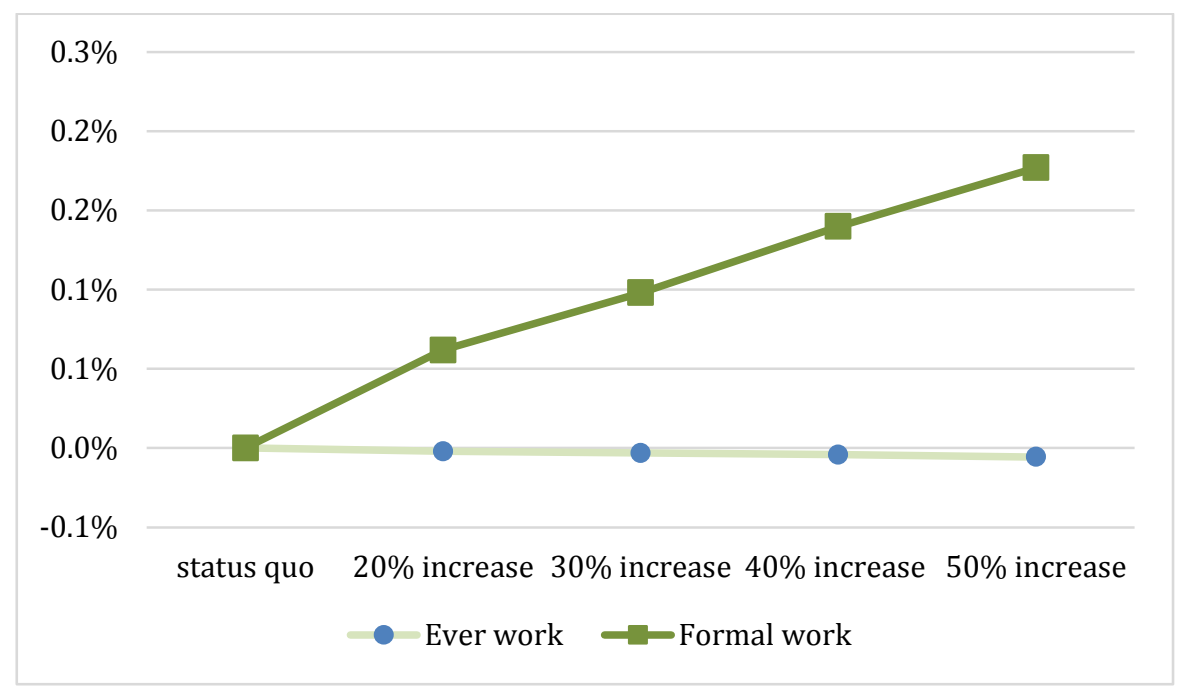

\section{Conclusions}

Mexico and China have made important progress toward extending social security coverage to a larger fraction of their populations. In only four years, China increased the proportion of individuals 70 and older who are covered from 33.5 percent to 73.2 percent. Likewise, the proportion covered of China's 65- to 70-year-old population increased from 31 percent in 2011 to 55.4 percent in 2015. A similar pattern was experienced by Mexico, albeit slightly slower. Once we account for both contributory and non-contributory programs, the proportion of individuals 70 and older covered increased from 33 percent in 2002 to 56 percent in 2012.

The growth of coverage has occurred primarily due to the expansion of non-contributory programs that aim to reach vulnerable groups. The Pension Schemes for Rural and Nonsalaried Urban Residents in China targets those living in rural areas and those who worked in the 
nonsalaried sector, effectively benefitting those with rural hukous who tend to be of low socioeconomic status. In Mexico, the Programa Pension para Adultos Mayores originally targeted rural areas, but was then expanded and currently targets anyone who does not have another form of pension. In the case of India, the Indira Gandhi Old Age Pension Program specifically targets the elderly living below the poverty line.

As a result, the characteristics of the covered population have changed dramatically. In the first wave of the data for China, among the older population, individuals covered by a public pension tended to be those with higher education, living in urban areas, with urban hukous, and a history in salaried employment. Only four years later, those same variables were negative predictors of coverage. Likewise, in 2002 in Mexico those covered by public pensions were mostly those receiving benefits from the contributory systems, and therefore were those who had worked for sufficiently long periods of time in the formal private or public sectors. By 2015, the majority of public pensioners were receiving benefits through the PPAM, many of them living in rural areas.

Separately for each survey wave, we estimated logistic regression models in which the dependent variable is an indicator of "receiving a public pension" and the regressors include education, marital status and other demographic predictors of employment, as well as rough indicators of work history in some models. Variables that were positive predictors in the first wave of MHAS and CHARLS become negative and statistically significant predictors by the last wave of analysis. Thus, we find a very fast transformation, where the labor market has been "decoupled" from the coverage of public pensions.

However, in China and Mexico, a very strong relationship remains between the labor market characteristics and the income pension amount. We find this relationship to be almost unchanged, which is a result of the much smaller amounts that are paid by the non-contributory programs. For instance, we find that though tertiary education negatively predicts receiving a 
pension in the last wave of the CHARLS and MHAS data, it predicts a pension that is many times higher than the average pension received by those with primary education (six times higher in China and 10 times higher in Mexico). Likewise, we do not find large significant changes between these variables and receipt of benefits from other social programs.

These patterns are apparent in our findings from our modeling and projections under alternative scenarios. We find that, for example, even a rapid transformation of the labor market will not radically change the population proportion covered by a pension program, but would indeed substantially increase average pension amounts. By the same token, increasing the population shares with secondary education would not largely change the coverage patterns in Mexico or China, but would substantially raise average pension income.

These results show that the introduction of noncontributory programs has brought about dramatic increases in coverage independent from the strength of labor markets or size of the formal sector. However, these findings also imply that strong labor markets are necessary to improve the benefit levels and economic security of future elderly populations. Therefore, continued growth and improvement of labor market opportunities are still crucial factors to increasing the wellbeing of these populations.

The harmonized longitudinal data that we use, as developed by the Gateway to Global Aging at the University of Southern California with support from the National Institute on Aging, has proven to be useful for capturing the fast transformations taking place in the social security landscapes in China and Mexico and for comparing patterns across these countries. Future rounds of these surveys will allow researchers to analyze further implications of these and other policy changes and economic transformations affecting the lives of the large and growing number of elderly in these countries. 


\section{References}

Aguila, E., Díaz, C. , Manqing, F., Kapteyn, A., \& Pierson, A. (2011). Envejecer en México: Condiciones de Vida y Salud. RAND Corporation. http://www.rand.org/pubs/monographs/MG1179z2.html

Aguila, E., Mejia, N., Perez-Arce, F., \& Rivera, A. (2013). Programas de Pensiones No Contributivas y su Viabilidad Financiera: El Caso de México, RAND Working Paper RR999.

Aterido, R., Hallward-Driemeier, M., \& Pagés, C. (2011). Does Expanding Health Insurance Beyond Formal-Sector Workers Encourage Informality?: Measuring the Impact of Mexico's Seguro Popular. The World Bank.

Beaumaster, S., Chien, S., Lau, S., Lin, A.,Philips, D., Wilkens, J., \& Lee, J. (2018) "Harmonized CHALRS Documentation. Version C. Center for Economic Social Research.

http://charls.pku.edu.cn/uploads/document/harmonized_charls/application/Harmonized_C HARLS_C.pdf

Bloom, D. E., Mahal, A., Rosenberg, L., \& Sevilla, J. (2010). Economic security arrangements in the context of population ageing in India. International Social Security Review, 63(3-4), 59-89.

Carone, G., Eckefeldt, P., Giamboni, L., Laine, V., \& Pamies, S. (2016). Pension Reforms in the EU since the Early 2000's: Achievements and Challenges Ahead.

The Economic Times, Jan 16, 2017. https://economictimes.indiatimes.com/wealth/save/nps-sees-

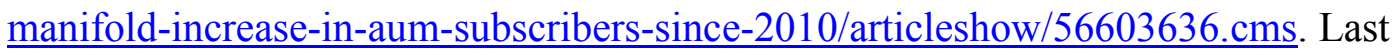
accessed on September 20, 2018

Giles, J., Wang, D., \& Park, A. (2013). Expanding Social Insurance Coverage in Urban China Labor Market Issues in China, Research in Labor Economics. 37, pp. 123-179.

ILO- International Labour Organization (2018). "World Social Protection Report. Universal social protection to achieve the Sustainable Development Goals". International Labour Office-Geneva. 
Kaplan, D. S., \& Perez Arce Novaro, Francisco. (2006). El efecto de los salarios mínimos en los ingresos laborales de México. El Trimestre Económico, 139-173.

Kaplan, D. S., \& Sadka, J. (2008). Enforceability of Labor Law: Evidence from a Labor Court in Mexico. The World Bank.

Lei, X., Zhang, C., \& Zhao, Y. (2013). Incentive Problems in China's New Rural Pension Program. In C. Giulietti, K. Tatsiramos, \& K. F. Zimmermann (Eds.), Research in Labor Economics. 37, pp. 181-201. Emerald Group Publishing Limited. https://doi.org/10.1108/S0147-9121(2013)0000037010

Liu, Zhiqiang. (2005) Institution and inequality: the hukou system in China. Journal of Comparative Economics, 33, 133-157

MHAS, Mexican Health and Aging Study, (2018). Data Files and Documentation (public use): Mexican Health and Aging Study. Retrieved from www.MHASweb.org on April, 2018.

OECD Data (n.d). Conversion rates - Purchasing power parities (PPP) - OECD Data. (n.d.). Retrieved September 25, 2018, from http://data.oecd.org/conversion/purchasing-powerparities-ppp.htm

Park, A., \& Cai, F. (2011). The informalization of the Chinese labor market. From Iron Rice Bowl to Informalization: Markets, Workers, and the State in a Changing China, 17.

PTI. (2017, January 16). NPS sees manifold increase in AUM, subscribers since 2010. The Economic Times.

Secretaría de Desarrollo Social, SEDESOL, (2007. "Reglas de Operación del Programa de Atención a los Adultos Mayores de 70 años y más en zonas rurales, para el ejercicio fiscal 2007', (2007).

SEDESOL. "Reglas de Operación del Programa de Atención a los Adultos Mayores de 70 años y más en zonas rurales, para el ejercicio fiscal 2008”, (2008).

SEDESOL. "Reglas de Operación del Programa 70 y más, para el Ejercicio Fiscal 2009”, (2009).

SEDESOL. "Reglas de Operación del Programa 70 y más, para el Ejercicio Fiscal 2012”, (2012).

SEDESOL. "Reglas de Operación del Programa 70 y más, para el Ejercicio Fiscal 2014”, (2014). 
Shah, A. (2006). Indian pension reform: A sustainable and scalable approach. In D. A. Kelly, R. S. Rajan, and G. H. L. Goh (Eds.), Managing Globalization: Lessons from China and India (pp. 167-218). Singapore: World Scientific. https://doi.org/10.1142/9789812774729 0007

Shankar, S., \& Asher, M. G. (2011). Micro-pensions in India: Issues and challenges. International Social Security Review, 64(2), 1-21.

Social Security Administration [SSA]. (2017). Social Security Programs Throughout the World: Asia and the Pacific, 2016. SSA Publication No. 13-11802. Washington, DC: Social Security Administration, Office of Retirement and Disability Policy \& Office of Research, Evaluation, and Statistics. https://www.ssa.gov/policy/docs/progdesc/ssptw/20162017/asia/index.html

Social Security Administration [SSA]. (2011). Mexico. In Social Security Programs Throughout the World: The Americas, 2011 (pp. 137-143). Social Security Administration.

State Council (2017) "National Population Development Outline”.

United Nations, UN (2017). “World Population Prospects. Key Findings and Advance Tables”. 2017 Revision. Department of Economic and Social Affairs. United Nations Publications. New York, NY.

Vilela, A., HelpAge International, Germany, \& Bundesministerium für Wirtschaftliche Zusammenarbeit und Entwicklung. (2013). Pension coverage in China and the expansion of the new rural social pension.

World Bank. (2016 a). Education in India. http://www.worldbank.org/en/news/feature/2011/09/20/education-in-india

World Bank (2016 b). "Live long and prosper: Aging in East Asia and Pacific". World Bank East Asia and Pacific Regional Report;. Washington, DC. World Bank. https://openknowledge.worldbank.org/handle/10986/23133

Xiaodong, W. (2017, January 27). Report: Sex ratio to balance out by 2030 - China Chinadaily.com.cn. China Daily. Retrieved from http://www.chinadaily.com.cn/china/2017-01/27/content_28064356.htm

Zhang, Chuanchuan, John Giles, and Yaohui Zhao. (2014). "Policy Evaluation of China's New Rural Pension Program: Income, Poverty, Expenditure, Subjective Wellbeing and Labor Supply." 


\section{A.2 Additional Figures for Counterfactual Scenarios}

Figure A.2.1: Simulations of the effect of increasing higher educational attainment and the share in urban areas on the proportion of the population $65+$ covered by Social Security

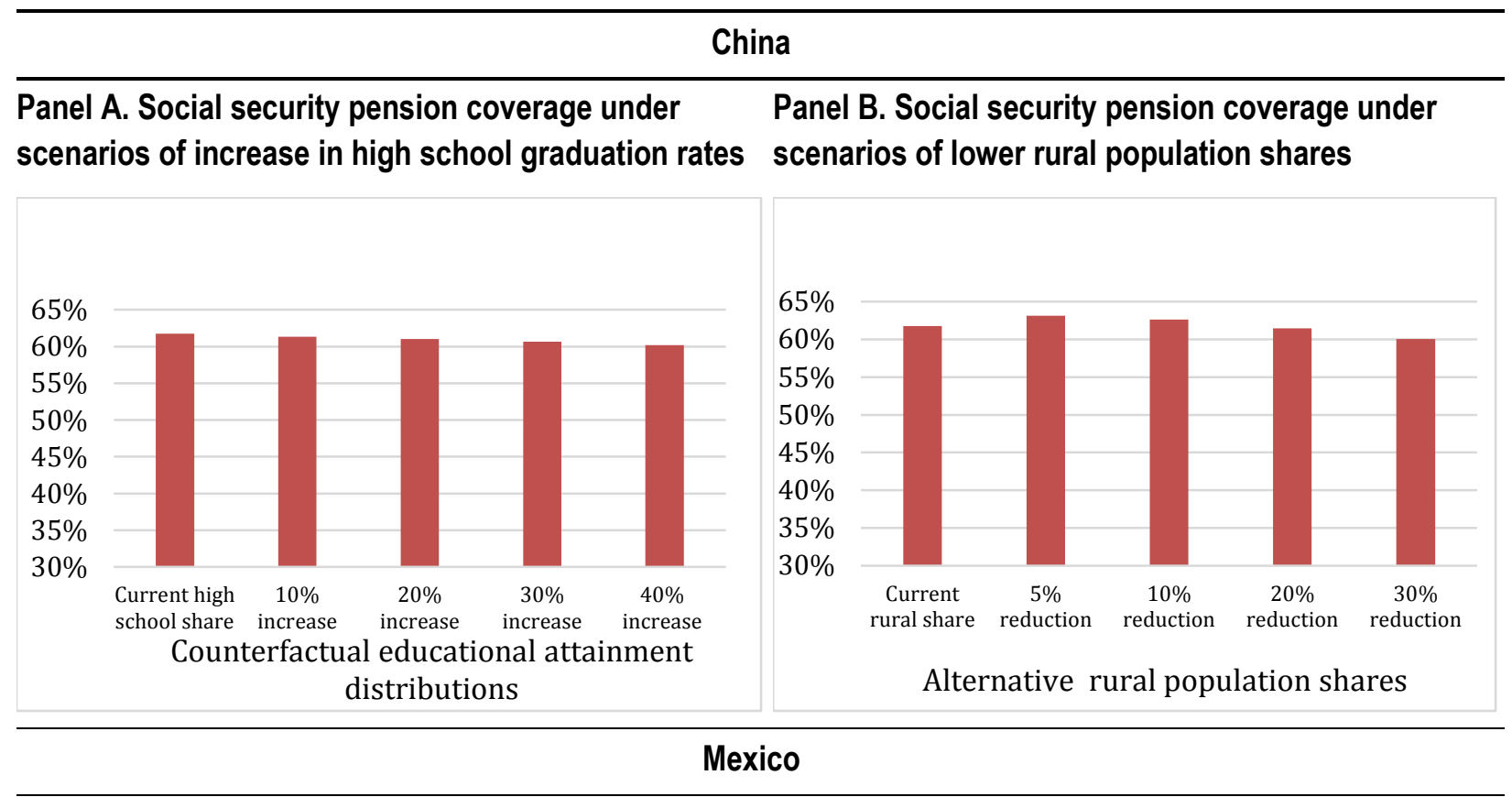

Panel A. Social security pension coverage under

Panel B. Social security pension coverage under scenarios of increase in high school graduation rates

scenarios of lower rural population shares
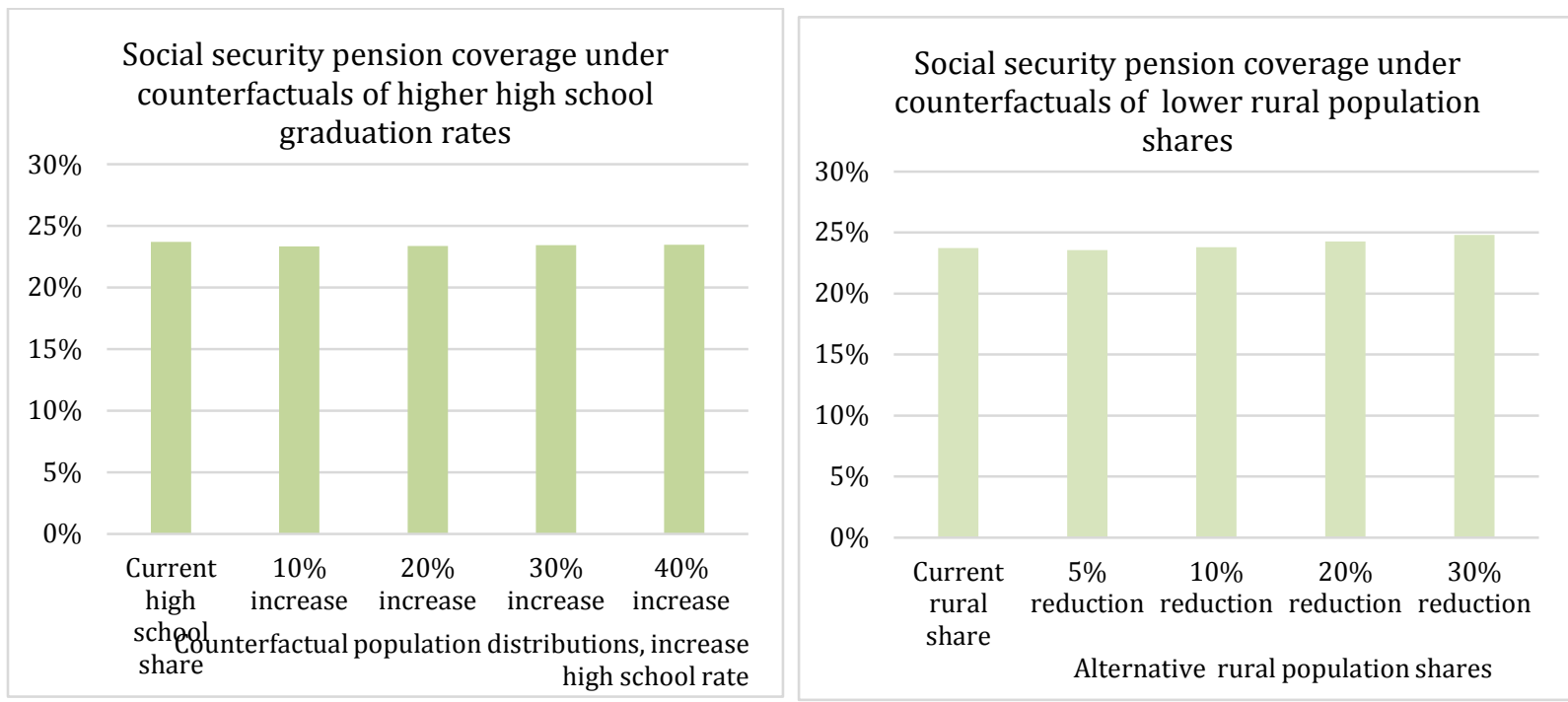